\title{
Assembly of the oncogenic DNA-binding complex LMOE-Ldb1-TAL1-E12
}

\author{
Daniel P. Ryan, Jaimee L. Duncan, Christopher Lee, Philip W. Kuchel, \\ and Jacqueline M. Matthews ${ }^{*}$
}

School of Molecular and Microbial Biosciences, University of Sydney, Sydney, New South Wales 2006, Australia

\begin{abstract}
The nuclear proteins TAL1 (T-cell acute leukaemia protein 1) and LMO2 (LIMonly protein 2) have critical roles in haematopoietic development, but are also often aberrantly activated in T-cell acute lymphoblastic leukaemia. TAL1 and LMO2 operate within multifactorial protein-DNA complexes that regulate gene expression in the developing blood cell. TAL1 is a tissue-specific basic helix-loophelix (bHLH) protein that binds bHLH domains of ubiquitous E-proteins, (E12 and E47), to bind E-box (CANNTG) DNA motifs. TAL $1_{b H L H}$ also interacts specifically with the LIM domains of LMO2, which in turn bind Ldb1 (LIM-domain binding protein 1). Here we used biophysical methods to characterize the assembly of a five-component complex containing TAL1, LMO2, Ldb1, E12, and DNA. The bHLH domains of TAL1 and E12 alone primarily formed helical homodimers, but together preferentially formed heterodimers, to which LMO2 bound with high affinity $\left(K_{A} \sim 10^{8}\right.$ $\left.M^{-1}\right)$. The resulting TAL1/E12/LMO2 complex formed in the presence or $a b$ sence of DNA, but the different complexes preferentially bound different Eboxsequences. Our data provide biophysical evidence for a mechanism, by which LMO2 and TAL1 both regulate transcription in normal blood cell development, and synergistically disrupt E2A function in T-cells to promote the onset of leukaemia.
\end{abstract}

Proteins 2008; 70:1461-1474.

(C) 2007 Wiley-Liss, Inc.

Key words: T-cell leukaemia; proteinDNA complex; TAL1; LMO2; protein/protein interactions.

\section{INTRODUCTION}

Acute lymphoblastic leukemia (ALL) is characterized by the accumulation of immature lymphoid progenitors, and is the most common form of neoplasia in children. T-cell ALL accounts for $\sim 10 \%$ of childhood leukemias and a further $25 \%$ of adult leukemias. ${ }^{1}$ Despite advances in treatments of ALL in the past $10-15$ years, $25-40 \%$ of children and adolescents with T-cell ALL still succumb to the disease. Laboratory and clinical markers that are used to guide treatment of the more common (and more successfully treated) B-cell leukemias, are of little use in the treatment of T-cell leukemias. Therefore, advances in treatment are unlikely to be made until the molecular bases of the causes of the disease are understood. ${ }^{1}$ More than half of all T-cell leukemias are associated with the over-expression of two proteins T-cell acute leukaemia protein 1 (TAL1)/SCL1 and LIM-only protein 2 (LMO2 or rhombotin 2), often as the result of specific chromosomal rearrangements $[t(1 ; 14)(\mathrm{p} 32 ; \mathrm{q} 11)$ and $t(11 ; 14)(\mathrm{p} 13 ; \mathrm{q} 11)$, respectively]. ${ }^{2,3}$ The over-expression of tall and/or $l m o 2$ in mice also results in the malignant transformation of T-cell lineages indicating that either protein can act as a T-cell oncogene. ${ }^{4,5}$ These effects are exacerbated when the genes are coexpressed, ${ }^{6}$ strongly suggesting that TAL1 and LMO2 have synergistic roles in the onset of some T-cell leukemias.

TAL1 is a tissue-specific basic helix-loop-helix (bHLH) transcription factor. These eukaryotic proteins are involved in cell differentiation and are characterized by a $\sim 50$-residue helix-loop-helix protein interaction domain, preceded by a $\sim 10$-residue basic region that binds DNA. ${ }^{7}$ TAL1 is thought to form heterodimers with ubiquitous bHLH factors, such as the E2A-proteins E12 and E47, before binding E-box (CANNTG) DNA motifs. ${ }^{7}$

$\mathrm{LMO} 2$ is a member of the LIM-only class of transcriptional coregulators that consist of little more than two closely spaced LIM-domains. LMOs act as protein-protein adaptors, mediating interactions via their LIM-domains to form specific multiprotein complexes. ${ }^{8}$ All four human LMO proteins (LMO1-LMO4) have been associated with oncogenesis. ${ }^{9-11}$

Both TAL1 and LMO2 are essential for hematopoietic development 12,13 and gene deletion studies of tall or lmo2 suggest overlapping roles for TAL1 and $\mathrm{LMO} 2$ in vivo. ${ }^{14,15}$ Indeed, multiprotein DNA-binding complexes that contain TAL1 and LMO2 have been isolated from erythroid and T-cell acute

The Supplementary Material referred to in this article can be found online at http://www.interscience.wiley. com/jpages/0887-3585/suppmat/

Grant sponsor: Australian Research Council.

${ }^{\star}$ Correspondence to: Jacqueline M. Matthews, School of Molecular and Microbial Biosciences, University of Sydney, Sydney, NSW 2006, Australia. E-mail: j.matthews@mmb.usyd.edu.au

Received 19 November 2006; Revised 27 April 2007; Accepted 27 May 2007

Published online 1 October 2007 in Wiley InterScience (www.interscience.wiley.com).

DOI: $10.1002 /$ prot.21638 
lymphoblastic leukaemia (T-ALL) cell lines. ${ }^{16-18}$ These complexes appear to be regulators of transcription and also contain the ubiquitous LIM domain-binding protein 1 (Ldb1) and E2A proteins (E47 or E12). The complexes also contain other factors, such as GATA-1 16 or Sp1.19

Some mice with non-functional E2A exhibit a partial block in the early stages of T-cell differentiation that leads to the development of T-cell leukemia. ${ }^{20}$ The resultant phenotype is similar to that of mice that carry transgenes for TAL1 and LMO2. ${ }^{4-6}$ It is thought that in these mice TAL1 blocks E2A-mediated gene expression, disrupting normal lymphocyte development that results in proliferation of immature T-cells and the onset of $\mathrm{T}$ cell leukemia. ${ }^{21-23}$ The potential role of LMO2 and the molecular basis for this process have not been fully characterized, although the networks of interactions involved in this process have been established (see Fig. 1).

The aim of this work was to determine the fundamental biophysical parameters that underlie the formation of complexes containing TAL1, LMO2, Ldb1, E12, and DNA. We generated the interacting domains of all of the proteins and target DNA sequences, and used various biophysical methods to estimate the association constants for all of the component equilibrium reactions. These association constants were used in a mathematical model to predict the distribution of those components among different possible complexes and subcomplexes. Our data provide biophysical support for the hypothesis that TAL1 and $\mathrm{LMO} 2$ act in concert to cause $\mathrm{T}$ cell leukemia through the disruption of normal E2A function. This quantitative molecular understanding is pertinent to the future development of specific anti-leukaemia agents.

\section{MATERIALS AND METHODS}

\section{Protein production}

All proteins were expressed in Escherichia coli BL21 (DE3) cells. The purification of LMO2-Ldb1 $1_{\text {LID }}$ has been described previously. 24 The bHLH domain of human TAL1 (residues 186-246; TAL1 $1_{\mathrm{bHLH}}$ ) was amplified by PCR from a k562 cDNA library and inserted into pRSET-A and pMAL-C2 derived expression plasmids. The bHLH domain of E12 (residues 549-610; E12 ${ }_{\mathrm{bHLH}}$ ) was subcloned into pGEX-2T- and pMAL-C2-derived plasmids. Codons within the TAL1 $1_{\mathrm{bHLH}}$ and $\mathrm{E} 12_{\mathrm{bHLH}}$ were then optimized for expression in E. coli using inverse PCR. All cloned DNA fragments were sequenced (SUPAMAC, The University of Sydney).

$\mathrm{TAL}_{\mathrm{bHLH}}$ was expressed with an N-terminal $\mathrm{His}_{6}$-tag and immobilized on Ni-NTA resin in guanidium hydrochloride $(\mathrm{GdmHCl})$ buffer $\left(100 \mathrm{mM} \mathrm{NaH}_{2} \mathrm{PO}_{4}(\mathrm{pH} 8.0)\right.$, $10 \mathrm{~m} M$ Tris- $\mathrm{HCl}, 6 \mathrm{M} \mathrm{GdmHCl}$ ), washed in urea buffer (100 $\mathrm{mM} \mathrm{NaH} \mathrm{PO}_{4}, 10 \mathrm{mM}$ Tris, $8 \mathrm{M}$ urea) at $\mathrm{pH} 6.3$ then $\mathrm{pH} 5.9$, and then eluted in urea buffer at $\mathrm{pH} 4.5$.

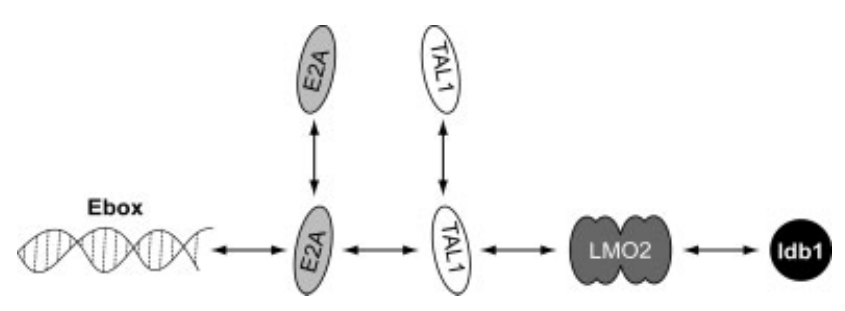

\section{Figure 1}

The interaction network involving LMO2, Ldb1, TAL1, E12, and DNA.

Schematic showing the individual protein-protein and protein-DNA interactions

that occur between LMO2, Ldb1, TAL1, E12, and DNA.

The urea was removed by dialysis and $\mathrm{TAL}_{\mathrm{bHLH}}$ was purified further by reverse-phase HPLC using an acetonitrile $(0-100 \% \quad \mathrm{v} / \mathrm{v}) /$ trifluoracetic acid $(0.1 \% \quad \mathrm{v} / \mathrm{v}) /$ water gradient $(100-0 \% \mathrm{v} / \mathrm{v})$ and lyophilised. E12 $\mathrm{bHLH}$ was expressed as a GST-fusion protein and purified on GSHsepharose under native conditions (50 mM Tris- $\mathrm{HCl}(\mathrm{pH}$ 7.0), $150 \mathrm{mM} \mathrm{NaCl}, 1 \mathrm{mM}$ dithiothreitol (DTT), $0.1 \%$ (v/v) Triton X-100, $0.5 \mathrm{mM}$ EDTA, $0.5 \mathrm{mM}$ PMSF) and, if required, the GST-tag was removed by treatment with PreScission ${ }^{\mathrm{TM}}$ protease. E12 ${ }_{\mathrm{bHLH}}$ was purified further by either cation-exchange chromatography using a MonoS $10 / 10$ column (GE Healthcare) and a $\mathrm{NaCl}$ gradient in $20 \mathrm{mM} \mathrm{NaH} \mathrm{PO}_{4}$ (pH 7.4) and $1 \mathrm{mM}$ DTT, or by reverse-phase HPLC in the same manner as TAL1 $1_{\mathrm{bHLH}}$. E12 $\mathrm{bHLH}$ was also expressed as a maltose-binding protein (MBP)-fusion protein and purified on Amylose resin (New England Biolabs) under native conditions [20 $\mathrm{mM}$ Tris ( $\mathrm{pH} 8.0$ ), $150 \mathrm{mM} \mathrm{NaCl}, 0.1 \%$ (v/v) $\beta$-mercaptoethanol, $0.5 \mathrm{mM}$ PMSF] and eluted as an intact fusion protein using $20 \mathrm{mM}$ maltose. Concentrations of TAL $1_{\mathrm{bHLH}}$ and LMO2-Ldb1 $1_{\text {LID }}$ were determined from their molar extinction coefficients $\left(17,600\right.$ and 22,900 $M^{-1} \mathrm{~cm}^{-1}$, respectively) at $280 \mathrm{~nm}$. The concentration of E12 $\mathrm{bHLH}$ (which lacks Tyr and Trp residues) was determined by $144 \times\left(A_{215} \mathrm{~nm}-A_{225 \mathrm{~nm}}\right){ }^{25}$

\section{Preparation of double-stranded oligonucleotides for biophysical experiments}

Oligonucleotides were supplied by Sigma-Genosys (Castle Hill, Australia). Equimolar amounts of complementary oligonucleotides (EboxGG: CCGCCAGGTG CTCG, CGAGCACCTGGCGG; EboxGC: CTATCAGCT GATGA, TCATCAGCTGATAG) were mixed in $20 \mathrm{mM}$ $\mathrm{NaH}_{2} \mathrm{PO}_{4}$ (pH 7.4) containing $150 \mathrm{mM} \mathrm{NaCl}, 1 \mathrm{mM}$ EDTA, and/or $1 \mathrm{mM}$ DTT. The oligonucleotides were denatured at $95^{\circ} \mathrm{C}$ for 5-10 $\mathrm{min}$ and annealed by cooling slowly to room temperature. Samples were stored shortterm at $4^{\circ} \mathrm{C}$ or long-term at $-20^{\circ} \mathrm{C}$. Concentrations of EboxGG and EboxGC were determined from their molar 
extinction coefficients $\left(225,000\right.$ and $245,000 \mathrm{M}^{-1} \mathrm{~cm}^{-1}$, respectively) at $254 \mathrm{~nm}$.

\section{Preparation of protein complexes by native metal-affinity chromatography}

Lyophilized samples of TAL $1_{\mathrm{bHLH}}(\sim 1 \mathrm{mg})$ were dissolved in 2.0-2.5 mL MQW and the $\mathrm{pH}$ adjusted to 7.4 by the addition of $\mathrm{NaH}_{2} \mathrm{PO}_{4}$ (final concentration 50-100 $\mathrm{mM}$ ). The dissolved protein was added to a column of $\mathrm{Ni}$-NTA resin (1-2 $\mathrm{mL}$ bed volume) pre-equilibrated in column buffer $\left(50 \mathrm{mM} \mathrm{NaH} \mathrm{PO}_{4}(\mathrm{pH} 7.4), 150 \mathrm{mM}\right.$ $\mathrm{NaCl}$ and $0.02 \%(\mathrm{v} / \mathrm{v}) \beta$-mercaptoethanol), and run by gravity-flow. The eluant was collected and reapplied to the column, and this process was repeated three times. The resin was then washed with $5 \mathrm{~mL}$ of column buffer. A sample containing an excess of E12 ${ }_{\mathrm{bHLH}}(2.0-2.5 \mathrm{~mL})$ was applied to the column and allowed to run by gravity-flow. The eluant was collected and reapplied to the column, and this process was repeated five times. The column was then washed with $5 \mathrm{~mL}$ of column buffer. Bound protein was eluted in $0.5-1.0 \mathrm{~mL}$ fractions using column buffer containing $250 \mathrm{mM}$ imidazole. Alternatively, samples of DNA or LMO2-Ldb1 $1_{\text {LID }}$ were added and bound in the same manner as $\mathrm{E} 12_{\mathrm{bHLH}}$, and the resultant complexes eluted. Samples were collected throughout the procedure and analyzed using SDS-PAGE.

\section{Electrophoretic mobility shift assays}

Reactions were performed in EMSA buffer $(10 \mathrm{mM}$ HEPES pH 7.8, $50 \mathrm{mM} \mathrm{KCl}, 5 \mathrm{mM} \mathrm{MgCl}, 1 \mathrm{mM}$ EDTA, 5\% (v/v) glycerol) that contained additional DTT $(1 \mathrm{mM})$, BSA $\left(33 \mu \mathrm{g} \mathrm{mL}^{-1}-30 \mathrm{mg} \mathrm{mL}^{-1}\right)$ and poly $\mathrm{d} I \mathrm{~d} C$ $\left(3.3 \mu \mathrm{g} \mathrm{mL} \mathrm{m}^{-1}\right)$, on ice. The order and timing of addition of components was, where appropriate: mixtures of proteins (10 min), $0.4 \mathrm{ng}{ }^{32} \mathrm{P}$-labeled double-stranded oligonucleotide $(\geq 10 \mathrm{~min})$, antibodies $\left(1-\mu \mathrm{L}\right.$ anti-His ${ }_{6}$ (GE Healthcare) or $1-\mu \mathrm{L}$ anti-MBP (New England Biolabs) monoclonal antibodies; $10 \mathrm{~min}$ ). Samples were incubated for $30 \mathrm{~min}$ after the addition of the oligonucleotide, then separated on $6 \%(\mathrm{w} / \mathrm{v})$ non-denaturing polyacrylamide gels made up in $0.5 \times \mathrm{TB}(45 \mathrm{mM}$ Tris, $45 \mathrm{mM}$ boric acid) at $4^{\circ} \mathrm{C}$. Gels were dried and analyzed using a PhosphorImager (Molecular Dynamics).

\section{GST-pulldown assays}

MBP and MBP-TAL1 $1_{\mathrm{bHLH}}$ were expressed in E. coli and lysates prepared in $20 \mathrm{mM}$ Tris ( $\mathrm{pH} 8.0), 150 \mathrm{mM}$ $\mathrm{NaCl}, 0.1 \%(\mathrm{v} / \mathrm{v}) \beta$-mercaptoethanol and $0.5 \mathrm{mM}$ PMSF. Lysates $(50-100 \mu \mathrm{L})$ and/or $75 \mu \mathrm{g}$ of purified LMO2Ldb $_{\text {LID }}$ were added to $\sim 20 \mu \mathrm{g}$ of GST/GST-E12 $2_{\mathrm{bHLH}}$ immobilized on GSH-resin, and the reaction mixture made up to a final volume of $500 \mu \mathrm{L}$ in pulldown buffer [20 $\mathrm{m} M$ Tris $(\mathrm{pH} 8.0), 150 \mathrm{mM} \mathrm{NaCl}, 0.5 \%(\mathrm{v} / \mathrm{v})$ IGEPAL CA-630, 0.1\% (v/v) $\beta$-mercaptoethanol, $500 \mu M$ PMSF].
The samples were incubated with mixing at $4^{\circ} \mathrm{C}$ for $\sim 1-2 \mathrm{~h}$ then washed three times in pulldown buffer containing $10 \%$ glycerol. The resin was then analyzed by SDS-PAGE to detect bound proteins.

\section{Circular dichroism spectropolarimetry}

Circular dichroism (CD) spectra were recorded at $25^{\circ} \mathrm{C}$ in 1 or $0.1-\mathrm{mm}$ pathlength cuvettes using a Neslab RTE-111 temperature-controlled Jasco J-720 spectropolarimeter that had been calibrated with a camphor-10sulfonic acid standard $\left(0.6 \mathrm{~g} \mathrm{~mL}^{-1}\right)$. Spectra were recorded in 10-20 mM Na ${ }_{2} \mathrm{HPO}_{4}(\mathrm{pH}$ 7.4) and $0-50 \mathrm{mM}$ $\mathrm{NaCl} ; 1 \mathrm{mM}$ DTT was included in E12 ${ }_{\mathrm{bHLH}}$ samples and $150 \mathrm{mM} \mathrm{NaF}$ replaced $\mathrm{NaCl}$ in titration experiments. Final spectra were the average of three scans, and were baseline corrected. Estimates of secondary structure were made using the CDPro suite of programs. ${ }^{26}$

\section{Analytical size-exclusion chromatography and multiangle laser-light scattering}

Chromatography was conducted on a Superose ${ }^{\mathrm{TM}} 12$ 10/30 column (GE Healthcare) at a flow rate of $0.5 \mathrm{~mL}$ $\min ^{-1}$ in PBSA $\left(20 \mathrm{mM} \mathrm{NaH}{ }_{2} \mathrm{PO}_{4}(\mathrm{pH} 7.4), 150 \mathrm{mM}\right.$ $\mathrm{NaCl}, 1 \mathrm{mM}$ DTT) and the eluting species monitored at $280,215,230$, or $254 \mathrm{~nm}$. Light scattering data were recorded on an in-line miniDawn Tristar laser-light scattering instrument (Wyatt Technology); and the concentrations of eluting species were determined using an inline Optilab DSP interferometric refractometer (Wyatt Technology). Refractive index increment $(\mathrm{d} n / \mathrm{d} c)$ estimates of 0.190 and $0.185 \mathrm{~mL} \mathrm{~g}^{-1}$ were used for protein $^{27}$ and DNA, 28 respectively.

\section{Analytical ultracentrifugation}

Data were acquired on an Optima ${ }^{\mathrm{TM}}$ XLA analytical ultracentrifuge (Beckman Instruments) using an An-60ti rotor, samples were prepared in PBSA and the same buffer was used as a reference solution. Sedimentation equilibrium data were obtained at three rotor speeds $\left(16,000,20,000,30,000 \mathrm{rpm}\right.$ for TAL- $1_{\mathrm{bHLH}}$ and 16,000 , 22,000 , and $28,000 \mathrm{rpm}$ for LMO2-ldb1 $1_{\text {LID }}$ ) at various protein concentrations (1.7 and 3.4 $\mu M \mathrm{TALl}_{\mathrm{bHLH}}$; 36, 18 , and $9 \mu M$ LMO2-ldb $\left.1_{\text {LID }}\right)$. Data were the average of 10 scans recorded at 230 or $280 \mathrm{~nm}$ and baseline-corrected with data recorded at $360 \mathrm{~nm}$. Data were analyzed in the program NONLIN using a nonlinear least-squares curve fitting algorithm. ${ }^{29}$ Sedimentation velocity experiments were run at $42,000 \mathrm{rpm}$ and data collected at 230 or $232 \mathrm{~nm}$ at 3-min intervals and the data were analyzed using SedFit. ${ }^{30}$ Protein partial specific volumes and solvent densities (1.0062 $\mathrm{g} \mathrm{mL}^{-1}$ ) were estimated using Sednterp. ${ }^{31}$ 


\section{Fluorescence spectrophotometry}

TAL $_{\text {bHLH }}$ was labeled with AlexaFluor ${ }^{\circledR} 488$ 5-TFP (Invitrogen) at a 10:1 weight-to-weight protein:dye ratio in $100 \mathrm{mM} \mathrm{NaHCO} 3$ (pH 8.1). Labeling reactions were allowed to proceed for $1.5-2.0 \mathrm{~h}$ at room temperature and then overnight at $4{ }^{\circ} \mathrm{C}$ with constant mixing. After labeling, precipitated proteins were collected by centrifugation $(12,000 \mathrm{~g}, 10 \mathrm{~min}$, room temperature), redissolved in $8 M$ urea, dialyzed overnight against $\sim 5 \mathrm{~L}$ of PBSB (50 $\mathrm{mM} \mathrm{NaH}{ }_{2} \mathrm{PO}_{4}, 150 \mathrm{mM} \mathrm{NaCl}$, and $1 \mathrm{mM}$ DTT) at $\mathrm{pH}$ 5.0 and then $\sim 5 \mathrm{~L}$ of $\mathrm{PBSB}$ at $\mathrm{pH}$ 7.4. The dialysate was centrifuged $(12,000 \mathrm{~g}, 10 \mathrm{~min}$, room temperatue) and the supernatant reserved for fluorescence anisotropy experiments. Samples were stored at $4^{\circ} \mathrm{C}$ until required. The extent of labeling was calculated as described in the manufacturer's manual and was typically between 0.5 and $1.0 \mathrm{~mol}$ dye (mol protein $)^{-1}$.

Fluorescence anisotropy experiments were conducted at $25^{\circ} \mathrm{C}$ in $\mathrm{PBSB}(\mathrm{pH} 7.4)$ on a Julabo-F12 temperature controlled Shimadzu RF-5301PC spectrofluorophotometer. Samples were excited at $495 \mathrm{~nm}$ and the emitted light was measured at $519 \mathrm{~nm}$ for 20-30 s at 1-s intervals and the signal averaged. Longpass filters (Coherent, Santa Clara, CA) were used on the excitation (GG-475) and emission (OG-515) sources. Fluorescence intensities were corrected for the buffer baseline.

Tryptophan fluorescence emission spectra of TAL $1_{\mathrm{bHLH}}$ $(0.5 \mu M)$ in the presence of increasing concentrations of E12 $\mathrm{bHLH}$ were recorded at $25^{\circ} \mathrm{C}$ in PBSB $(\mathrm{pH} 7.4)$ on a Cary Eclipse fluorescence spectrophotometer fitted with a Cary Temperature Controller (Varian). Samples were excited at a wavelength of $285 \mathrm{~nm}$ and the emission spectrum was recorded between $315-385 \mathrm{~nm}$ at a speed of $60 \mathrm{~nm} \mathrm{~min}{ }^{-1}$ and $0.5 \mathrm{~nm}$ resolution. Final spectra were the average of three scans and the baseline was corrected for the buffer. Data from tryptophan titration experiments were normalized as follows. Ratios of fluorescence intensity at two separate wavelengths were calculated $\left(I_{\lambda_{1}} / I_{\lambda_{2}}\right)$ for each concentration point in the titration. These ratios were then substituted into Eq. (1).

$$
I_{\text {norm }}=\frac{I_{i}-I_{\min }}{I_{\max }-I_{\min }}
$$

$I_{\text {norm }}$ is the normalized intensity ratio; $I_{i}$ is the intensity ratio $\left(I_{\lambda_{1}} / I_{\lambda 2}\right)$ at the concentration point $i ; I_{\min }$ is the average minimum intensity ratio for the experiment; $I_{\max }$ is the average maximum intensity ratio for the experiment. This process was repeated at several other wavelength combinations, and the normalized values for each concentration point were averaged.

Protein homo- and hetero-dimerization data were analyzed using nonlinear least-squares fitting of models in MicroCal Origin 6.0 (MicroCal). The models used were either in-built in Origin 6.0 or based on standard homo[Eq. (2)] or heterodimerization [Eq. (3)] equilibria.

$$
\begin{gathered}
\Phi_{\mathrm{obs}}= \\
\Phi_{\mathrm{M}}+\left(\Phi_{\mathrm{D}}-\Phi_{\mathrm{M}}\right)\left\{\frac{4 A_{\mathrm{tot}}+\frac{1}{K_{\mathrm{A}}}-\sqrt{\frac{1}{K_{\mathrm{A}}}\left(8 A_{\mathrm{tot}}+\frac{1}{K_{\mathrm{A}}}\right)}}{4 A_{\mathrm{tot}}}\right\}, \\
\Phi_{\mathrm{obs}}=\Phi_{\mathrm{M}}+\left(\Phi_{\mathrm{D}}-\Phi_{\mathrm{M}}\right) \frac{1}{2 K_{\mathrm{AB}}} \\
\quad \times\left\{1+A_{\mathrm{tot}} K_{\mathrm{AB}}+B_{\mathrm{tot}} K_{\mathrm{AB}}\right. \\
\left.-\sqrt{-4 A_{\mathrm{tot}} B_{\mathrm{tot}} K_{\mathrm{AB}}{ }^{2}+\left(1+A_{\mathrm{tot}} K_{\mathrm{AB}}+B_{\mathrm{tot}} K_{\mathrm{AB}}\right)^{2}}\right\}
\end{gathered}
$$

where, $A_{\text {tot }}$ is the total concentration of the molecule under observation, $B_{\text {tot }}$ is the total titrant concentration [Eq. (3) only], "obs" is the experimentally observed signal at a particular titration point, " $\mathrm{M}$ " is the signal corresponding to unbound/monomeric protein, " $\mathrm{D}$ " is the signal corresponding to bound/dimeric protein, and $K_{\mathrm{A}}$ and $K_{\mathrm{AB}}$ are the equilibrium association constants for homodimerization and heterodimerization, respectively.

Mathematical expression describing competition between $\mathrm{TAL}_{\mathrm{bHLH}}$ homodimerization and $\mathrm{TAL}_{\mathrm{bHLH}^{-}}$ E12 $\mathrm{bHLH}$ heterodimerization were generated in Mathematica 4.0 software (Wolfram Research), where TAL1 $1_{\mathrm{bHLH}}$ concentration and $K_{\mathrm{TT}}$ were fixed and $K_{\mathrm{TE}}$ was varied. Simulated titration data sets comprised a series of calculations using the experimental range of E12 ${ }_{\mathrm{bHLH}}$ concentrations and a different value for $K_{\mathrm{TE}}$.

\section{Isothermal titration calorimetry}

Purified proteins, protein complexes and doublestranded DNA (see Supplementary Data 1 for concentrations) were dialyzed overnight at $4{ }^{\circ} \mathrm{C}$ against several litres of PBSA (20 mM NaH${ }_{2} \mathrm{PO}_{4}(\mathrm{pH} 7.4), 150 \mathrm{mM} \mathrm{NaCl}$, $1 \mathrm{mM}$ DTT) in the same reservoir. Samples were centrifuged $\left(10,000 \mathrm{~g}, 4^{\circ} \mathrm{C}, 10 \mathrm{~min}\right)$, degassed and equilibrated to $25^{\circ} \mathrm{C}$. All experiments were performed at $25^{\circ} \mathrm{C}$ using a VP-Isothermal titration calorimetry (ITC) microcalorimeter (MicroCal). Baseline data were measured by titration of the titrant into PBSA and subtracted from experimental data. Data were analyzed using the Origin 5.0 ITC data analysis software package (MicroCal) to generate estimates of stoichiometry, association constant $K_{\mathrm{A}}$, change in enthalpy $(\Delta H)$, and change in entropy $(\Delta S)$. Changes in Gibbs' free energy $(\Delta G)$ were calculated by $\Delta G=\Delta H-T \Delta S$ or $\Delta G=-R T \ln \left(K_{\mathrm{A}}\right)$ where $T$ is the temperature in Kelvin $(298 \mathrm{~K})$, and $R$ is the gas constant. 


\section{Simulations of competing equilibria}

The Mathematica 5.2 add-on package MetabolicControlAnalysis 32,33 was used to translate the competing equilibria into a kinetic model. The values of on rate constants were estimated (to range from the diffusion limit of $10^{8}-10^{3} M^{-1} \mathrm{~s}^{-1}$ ). The off rate constants were calculated from the assumed value of the on rate constant divided by the association constant. All of the known competing equilibria were defined, and the initial monomeric species concentrations $(0.1-10 \mu M)$ were chosen to reflect experimental conditions (e.g., EMSA concentrations) or as best guess estimates of nuclear protein concentrations. The concentrations of complexes were initially set to a non-zero value $\sim 0.1 \%$ of the primary monomeric reagents. The changes to concentrations of monomers and complexes were simulated over a time sufficient to reach equilibrium (e.g., $\sim 5 \mathrm{~min}$ with $k_{\text {on }}$ values of $\left.10^{6} \mathrm{M}^{-1} \mathrm{~s}^{-1}\right)$.

\section{RESULTS}

\section{Characterization of individual components}

We first characterized the domains of each protein that were directly involved in LMO2/Ldb1/TAL1/E12/DNA complex formation: the LIM domains of LMO2, Ldb1 $1_{\text {LID }}$, $\mathrm{TAL}_{\mathrm{bHLH}}$, and E12 ${ }_{\mathrm{bHLH}}$ [Fig. 2(a)], and a doublestranded Ebox motif (CCGCCAGGTGCTCG; EboxGG) the sequence of which is based on site-selection experiments ${ }^{16}$ that identified consensus DNA sequences that were bound by complexes containing TAL1, E2A proteins, and LMO2. Recombinant LMO2 is unstable in solution; however, it can be stabilized by engineering chimeric proteins, in which LMO2 is fused to $\mathrm{Ldb} 1_{\mathrm{LID}}$ via a flexible linker [LMO2-Ldb1 $1_{\text {LID }}$ Fig. 2(b)]. 24,34 These intramolecular LMO-Ldb1 $1_{\text {LID }}$ complexes have native-like structure. $^{24,35}$ Unless otherwise stated, TAL1 $1_{\mathrm{bHLH}}$ contained an $\mathrm{N}$-terminal $\mathrm{HIS}_{6}$-tag, whereas $\mathrm{E} 12_{\mathrm{bHLH}}$ was either purified away from a GST-affinity tag or fused to the C-terminus of MBP (MBP-E12 $2_{\mathrm{bHLH}}$ ).

LMO2-Ldb $1_{\text {LID }}$, double-stranded EboxGG, TAL1 $1_{\mathrm{bHLH}}$, and $\mathrm{E} 12_{\mathrm{bHLH}}$ were all subjected to size exclusion chromatography monitored by multiangle laser light scattering to assess their oligomeric states. EboxGG and LMO2Ldb1 $1_{\text {LID }}$ each eluted as a single peak by gel filtration, with relative molecular masses $(\mathrm{Mr})$ corresponding to a double-stranded 14 bp DNA molecule $[8.9 \pm 0.6 \mathrm{kDa}$ cf. theoretical Mr $8.5 \mathrm{kDa}$; Fig. 3(a)], and a monomer [22.0 $\pm 0.5 \mathrm{kDa}$ cf. theoretical Mr $19.8 \mathrm{kDa}$; Fig. 3(b)], respectively. TAL $1_{\mathrm{bHLH}}$ eluted as a single peak with a $\mathrm{Mr}$ of $20.6 \pm 1.0 \mathrm{kDa}$ [Fig. 5(a)] indicating the formation of a discrete homodimer (theoretical Mr $18.4 \mathrm{kDa}$ ). Sedimentation equilibrium analysis was used to confirm the solution molecular weight estimates for LMO2-Ldb1 $1_{\text {IID }}[\mathrm{Mr}$ (a)

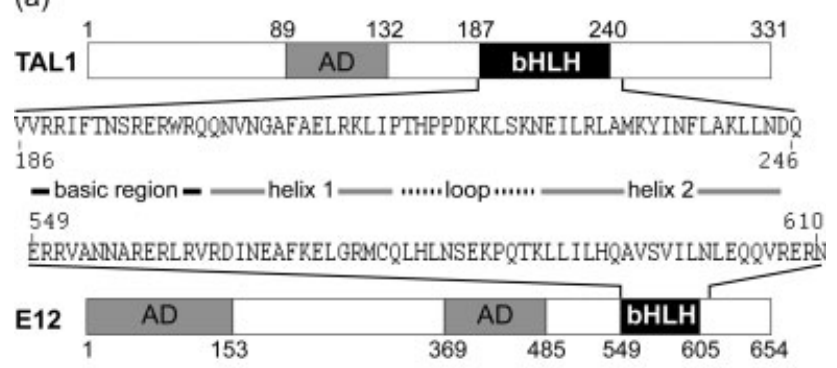

(b)

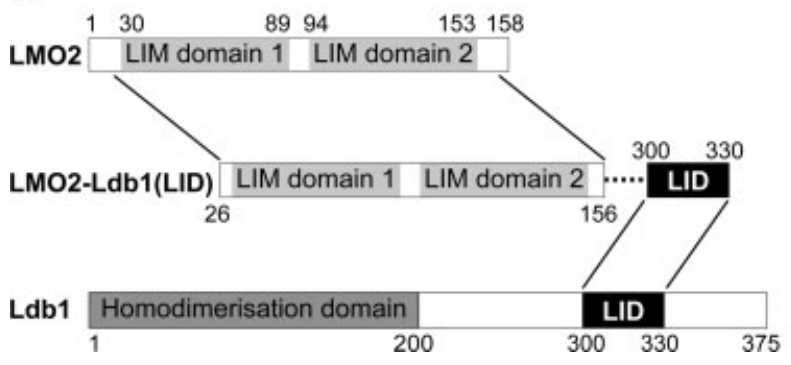

Figure 2

Protein constructs used in these studies. (a) The domain structure of TAL1 and E12 and the amino acid sequences of their bHLH domains. (b) Schematic showing the construction of the LMO2-Ldb1 $1_{L I D}$ chimera.

$20.4 \pm 1.1$, Fig. 3(c)] and TAL $1_{\mathrm{bHLH}}[\mathrm{Mr} 18.3 \pm 1.5$ kDa; Fig. 4(a)].

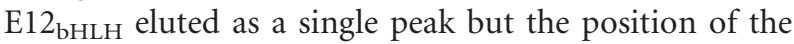
peak shifted according to the protein concentration [Fig. 4(b)]. At higher concentrations of protein $(\sim 50 \mu M)$ this peak had a lower retention time and a solution $\mathrm{Mr}$ corresponding to a dimer $[16.1 \pm 0.3 \mathrm{kDa}$ cf. theoretical $\mathrm{Mr}$ 15.6 kDa; Fig. 4(d) upper panel and Fig. 5(a)]. At lower protein concentrations the retention time increased, consistent with the protein eluting as a monomer, or in an apparent monomer-dimer equilibrium [Fig. 4(b) lower panels]. Multiangle laser light scattering analysis at the lower concentrations was not possible because of low signal: noise ratios. Sedimentation equilibrium analysis of the E12 ${ }_{\text {bHLH }}$ samples was not feasible as the system did not come to equilibrium, probably because of the slow formation of aggregates. Thus, sedimentation velocity analysis, using a loading concentration of $\sim 15 \mu M$, was used to further investigate the oligomeric state this protein. Data were fitted by a continuous $\mathrm{C}(S)$ distribution, revealing a main peak ( $\sim 50 \%$ of the population) with a sedimentation coefficient of $\sim 1.4$, a secondary peak $(\sim 21 \%)$ with a sedimentation coefficient of $\sim 2.6$, and a series of additional peaks of smaller size [Fig. 4(c)]. This indicates that monomeric E12 $2_{\mathrm{bHLH}}$ can associate to form dimers and a wide range of higher order oligomeric species.

Far-UV CD confirmed that both TAL $1_{\mathrm{bHLH}}$ and E12 ${ }_{\mathrm{bHLH}}$ formed $\alpha$-helical structure. Under physiological 
(a)

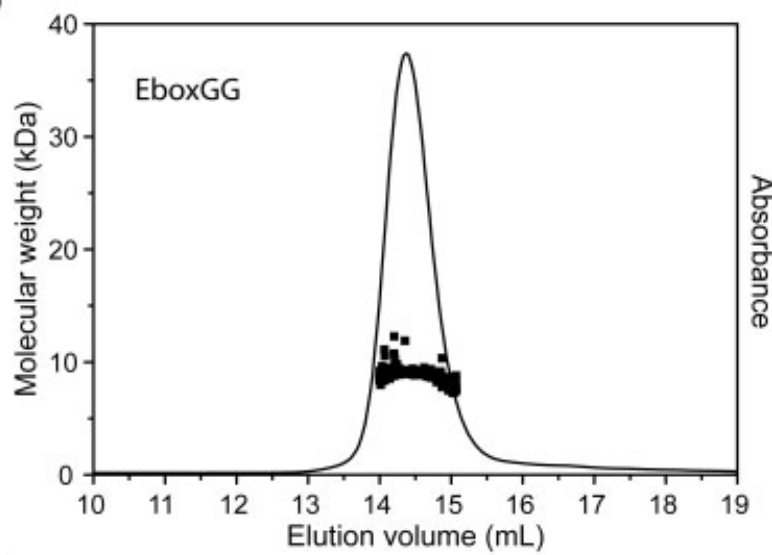

(b)

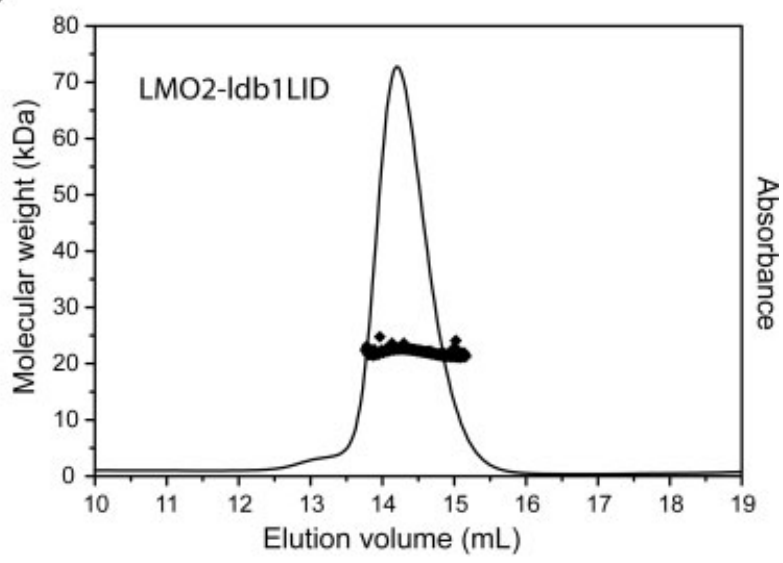

(c)

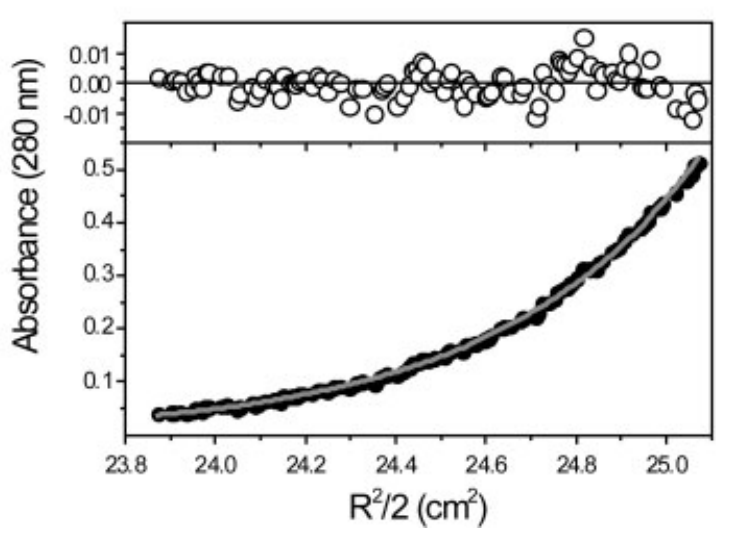

Figure 3

Characterization of EboxGG and LMO2-Ldb1 $1_{L I D}$. SEC/MALLs analysis of (a) EboxGG (loading concentration $100 \mu M$ ) and (b) the LMO2-Ldb1 $1_{L I D}$ chimera (loading concentration $\sim 300 \mu M$ ). (c) Sedimentation equilibrium analysis of the solution association state of $L M O 2-L d b 1_{L I D}$. Lower panel shows a plot of absorbance $(280 \mathrm{~nm})$ versus radial position (grey circles) for a sample of $L M O 2-L d b 1_{L I D}(36 \mu \mathrm{M}, 28,000 \mathrm{rpm})$ and the fit for an ideal single species model (solid grey line). Upper panel shows the residual deviations of the experimental data from the fitted ideal single species model.

conditions both TAL $1_{\mathrm{bHLH}}(7 \mu M)$ and $\mathrm{E} 12_{\mathrm{bHLH}}(10 \mu M)$ showed the double minima at 208 and $222 \mathrm{~nm}$, that is, characteristic of $\alpha$-helical structure [Fig. 4(d)]; they were estimated to contain $76 \% \pm 8 \%$ and $58 \% \pm 3 \% \alpha$-helix at these concentrations, respectively.

\section{Measurement of TAL $1_{\text {bHLH }}$ homodimerization $\left[K_{\mathrm{TT}}\right)$}

In this study a range of different techniques was required to determine the different association constants; no single technique was appropriate for all systems. In general, ITC was used to assess heteroassociation where no rearrangement of the complex components was evident. Spectroscopic methods were used to assess homooligomerization and complex equilibria.

Fluorescence anisotropy was used to determine the $K_{\mathrm{A}}$ for TAL $1_{\mathrm{bHLH}}$ homodimerization $\left(K_{\mathrm{TT}}\right)$. TAL1 $1_{\mathrm{bHLH}}$ was labeled with AlexaFluor ${ }^{\circledR} 488$ and a sample assayed by SEC/MALLS to demonstrate that the labeled protein still forms a dimer of the correct molecular weight (Supplementary Data 2). The labeled protein was then serially diluted from 4.2 to $26 \mathrm{nM}$ and the fluorescence anisotropy of each sample was measured. A graph of log $\left[\mathrm{TAL}_{\mathrm{bHLH}}\right]$ versus fluorescence anisotropy was sigmoidal [Fig. 4(e)]; this decrease in anisotropy is consistent with a decrease in apparent Mr. A change from 90 to $10 \%$ dimer in an ideal monomer-dimer equilibrium should accompany a concentration change of $2.86 \log$ units, rather than the $\sim 1.5 \log$ units evident in Figure $4(\mathrm{e})$. It is possible that the labeled protein also forms small amounts of soluble aggregate causing this relatively rapid change; however, similar observations are not uncommon ${ }^{36-39}$ and the inflexion point of the transition (as determined from a fit to a logistic function; $y=\left(A_{1}-\right.$ $\left.\left.A_{2}\right) /\left[1+\left(x / x_{0}\right) p\right]+A_{2}\right)$, where $A_{1}$ and $A_{2}$ are the initial and final values of anisotropy, $x$ is the concentration, $p$ is the power, and $x_{0}$ is the concentration at the inflexion point) is a good approximation of the equilibrium dissociation constant $\left(K_{\mathrm{D}}\right)^{38}$; this corresponded to $0.19 \pm$ $0.01 \mu M$ for $\operatorname{TAL}_{\mathrm{bHLH}}\left(K_{\mathrm{TT}}=5.3 d \times 10^{6} \mathrm{M}^{-1}\right)$.

\section{Measurement of E12 self-association $\left[K_{E E}\right.$ ]}

The self-association of E12 $\mathrm{bHLH}_{\mathrm{HLH}}$ was not assessable by fluorescence anisotropy as the AlexaFluor ${ }^{\circledR}$ 488-labeled protein was relatively insoluble; at low protein concentrations $(5 \mu M)$ the anisotropy signal was negligible, consistent with the protein being largely unfolded and monomeric.

Far-UV CD analysis of bHLH domains from $\mathrm{MyoD}^{40}$ and MASH- ${ }^{39}$ showed that a loss in $\alpha$-helical structure of the bHLH domains accompanied dissociation of the bHLH dimer. Therefore in a similar manner, we used far-UV CD to estimate the $K_{\mathrm{A}}$ of E12 $2_{\mathrm{bHLH}}$ self-association $\left(K_{\mathrm{EE}}\right)$. Upon dilution of E12 $2_{\mathrm{bHLH}}$, changes in the helical content of $\mathrm{E} 12_{\mathrm{bHLH}}$ were evident over a concentration range of 5-30 $\mu M$ [Fig. 4(f)] and present as a monophasic transition. The mid-point of the transition, $\sim 13.5$ 
(a)

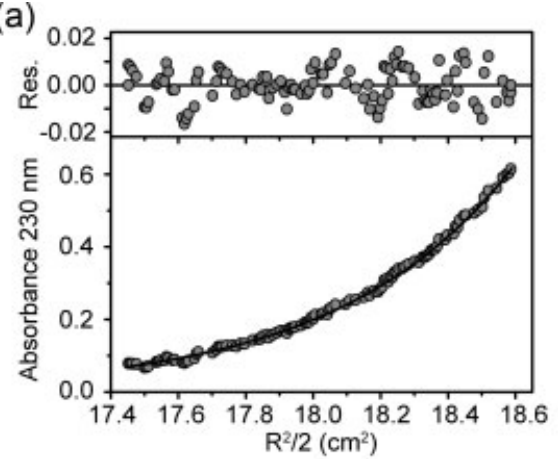

(d)

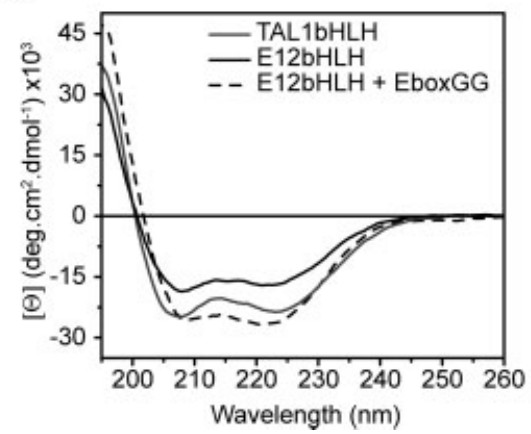

(b)

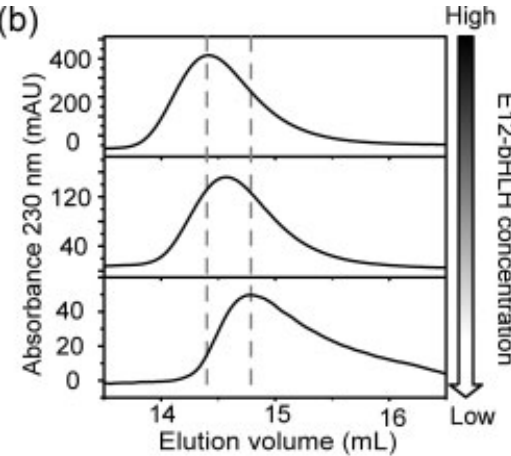

(e)

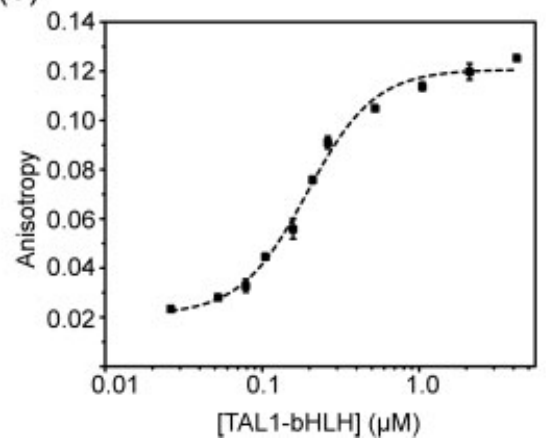

(c)

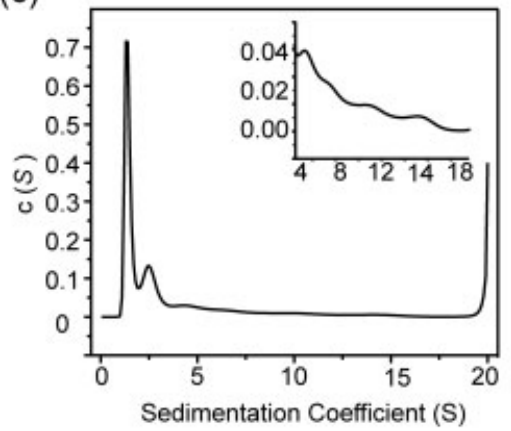

(f)

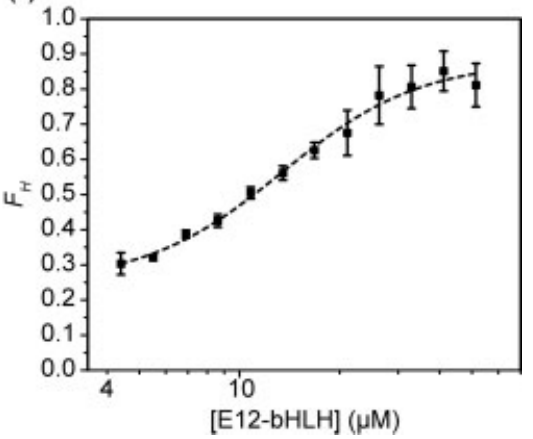

Figure 4

Characterization of TAL1 $1_{b H L H}$ and E12 $2_{b H L H}$. (a) Sedimentation equilibrium analysis of the solution association state of TAL1 $1_{b H L H}$. Lower panel shows a plot of absorbance $\left(230 \mathrm{~nm}\right.$ ) versus radial position (grey circles) for a sample of TAL1 $1_{b H L H}(3.4 \mu \mathrm{M}, 30,000 \mathrm{rpm}$ ) and the fit for an ideal single species model (solid line). Upper panel shows the residual deviations of the experimental data from the fitted ideal single species model. (b) E12 ${ }_{b H L H}(55 \mu M)$ was subjected to SEC (upper panel), the peak was collected and resubjected to SEC (middle panel), and this process repeated for the intermediate sample (lower panel). Elution volumes for starting (upper panel) and finishing (lower panel) sample are marked by dashed lines. (c) Sedimentation velocity data for E12 $2_{b H L H}$ (15 $\mu M$ ). Data (150 scans collected at 3-min intervals) were analyzed using a continuous $C(S)$ distribution models. The inset is an expansion from $\sim S=4-18$. (d) Far-UV CD spectra of TAL1 $1_{b H L H}$ (grey; $7 \mu M$ ), E12 ${ }_{b H L H}$ (black; $10 \mu \mathrm{M})$ and $E 12_{b H L H}\left(10 \mu \mathrm{M}\right.$ with the addition of equimolar EboxGG dashed line) recorded at $25^{\circ} \mathrm{C}$. (e) The fluorescence anisotropy of AlexaFluor ${ }^{\mathrm{R}}$ 488-labeled $T A L 1_{b H L H}$ at varying protein concentrations at $25^{\circ} \mathrm{C}$. $(\boldsymbol{f})$ Concentration dependence of the helical content $\left(F_{H}\right)$ of $E 12_{b H L H}$ as determine by far $U V$-CD.

(a)

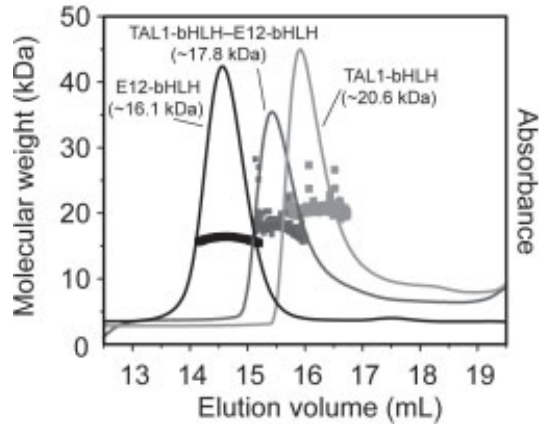

(b)

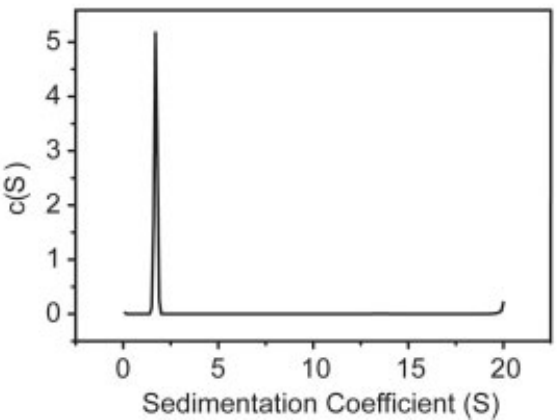

(c)

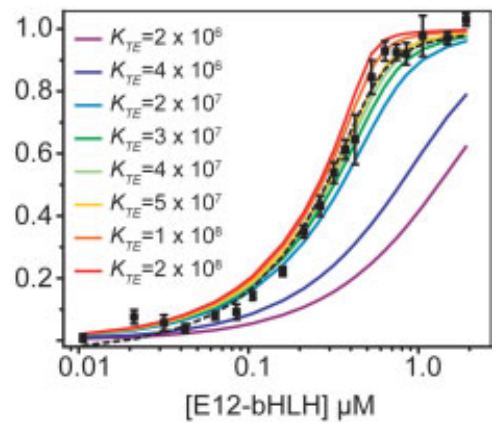

Figure 5

Characterization of TAL $L_{b H L H} / E 12_{b H L H}$ heterodimerization. (a) SEC/MALLS analysis of E12 ${ }_{b H L H}$ (black; loading concentration $55 \mu M$ ), TAL $1_{b H L H}$ (light grey; loading concentration $57 \mu \mathrm{M}$ ), and a TAL1 $1_{b H L H} / E 12_{b H L H}$ heterodimer (dark grey; loading concentration $\sim 30 \mu M$ ). (b) Sedimentation velocity analysis of a 1:1 mix of TAL1 $1_{b H L H} /$ E12 ${ }_{b H L H}(15 \mu M)$. Data (150 scans recorded at 3-min intervals) were analyzed using Sedfit using a continuous C(S) distribution model. The observed peak has a sedimentation coefficient $S=1.72 \pm 0.09$, frictional coefficient $f=1.3$, and estimated molecular weight of $15.3 \mathrm{kDa}$. (c) Tryptophan fluorescence of TAL1 ${ }_{b H L H}(0.5 \mu M$ ) titrated with $E 12_{b H L H}$ at $25^{\circ} \mathrm{C}$. Dashed line shows a fit a model for heterodimerization. Coloured lines are simulated data sets, for competition between TAL $1_{b H L H}$ homodimerization and heterodimerization with $E 12_{b H L H}$, obtained using different values for $K_{T E}\left(\right.$ as indicated in $M^{-1}$ units) and a fixed value for $K_{T T}\left(5.3 \times 10^{6} M^{-1}\right.$ ). 
$\pm 1.1 \mu M$, was determined by fitting the data with a logistic function. The rapid change in signal with changing concentration likely arises from the formation of multiple higher order species. In comparison, no significant change in the CD spectrum of TAL $1_{\mathrm{bHLH}}$ was observed over a similar concentration range, consistent with that protein existing as the homodimeric complex at concentrations above $\sim 2 \mu M$. It is noted that the sample of E12 $2_{\mathrm{bHLH}}$ used for Figure $4(\mathrm{~d})$ was a mixture of monomer and other species. Samples containing little or no monomer E12 [ 30 $\mu M$; Fig. 4(f)] were estimated to have an $\alpha$-helical content of $\sim 80 \%$-the same helical content as dimeric TAL1 $1_{\mathrm{bHLH}}$. We surmise that at low concentrations $\mathrm{E} 12_{\mathrm{bHLH}}$ is monomeric and partially unfolded, but associates to form homodimers and higher order species with an apparent $K_{\mathrm{D}}$ of $13.5 \mu M$ (viz. $K_{\mathrm{EE} \text {,app }} \approx 7.4 \times 10^{4} \mathrm{M}^{-1}$ ). This is consistent with studies that showed no self-association of full-length E12 at low concentrations, but suggest that small changes in fluorescence anisotropy described for a Dansyl-labeled full length E12 at $\sim 20 \mu \mathrm{M}$ protein concentration were significant and indicated self-association of the protein. 41

\section{Measurement of TAL1 $1_{\mathrm{bH}}-\mathrm{E}_{\mathrm{H}} \mathrm{2}_{\mathrm{bH}}$ heterodimerization $\left(K_{\text {TE }}\right)$}

In general, it is thought that TAL1 must heterodimerise with E12 (or other ubiquitous bHLH proteins) before it can bind to DNA. 7 To determine whether heterodimerization occurs in the absence of DNA, TAL $1_{\mathrm{bHLH}}$ and E12 ${ }_{\text {bHLH }}$ were subjected to size exclusion chromatography monitored by multiangle laser light scattering. Equimolar mixtures of $\mathrm{TAL}_{\mathrm{bHLH}}$ and $\mathrm{E} 12_{\mathrm{bHLH}}$ gave rise to an elution volume $(15.43 \mathrm{~mL})$ that was intermediate to those for $\mathrm{TAL}_{\mathrm{bHLH}}$ and E12 $\mathrm{bHLH}$ [Fig. 5(a)]. This corresponded to a molecular weight estimate of $17.8 \pm 1.1$ $\mathrm{kDa}$ compared with the theoretical value of the heterodimer of $17 \mathrm{kDa}$. Sedimentation velocity data collected on an equimolar mixture of $\mathrm{TAL}_{\mathrm{bHLH}}(15 \mu M)$ and E12 ${ }_{\mathrm{bHLH}}(15 \mu \mathrm{M})$ shows only a single sedimenting species, confirming they form a 1:1 heterodimer [Fig. 5(b)].

Intrinsic tryptophan fluorescence was used to estimate the $K_{\mathrm{A}}$ for the formation of the TAL $1_{\mathrm{bHLH}}-\mathrm{E} 12_{\mathrm{bHLH}}$ heterodimer $\left(K_{\mathrm{TE}}\right)$. TAL1 $1_{\mathrm{bHLH}}$ contains a single Trp residue (W198) in the basic region that extends the first $\alpha$-helix of the bHLH domain [Fig. 2(a)], whereas E12 ${ }_{\mathrm{bHLH}}$ contains no Trp residues. Titration of E12 ${ }_{\mathrm{bHLH}}$ into a constant concentration of $\mathrm{TAL}_{\mathrm{bHLH}}(0.5 \mu M)$ caused a red shift in the fluorescence emission maximum, $\lambda_{\max }$, from 344 to $348 \mathrm{~nm}$. This shift of fluorescence maximum was monitored using the ratio of fluorescence intensity at wavelengths either side of $\lambda_{\max }$ [Fig. 5(c)]. When fitted by an equation that describes a simple monomer-dimer equilibrium the apparent association constant $K_{\mathrm{TE}}$ had the value $(3.5 \pm 0.6) \times 10^{7} \mathrm{M}^{-1}$. This value does not take into account the effect of competition for hetero- dimer formation by homo-oligomerization of $\mathrm{E} 12_{\mathrm{bHLH}}$ or TAL $1_{\text {bHLH }}$ so it is simply an estimate. However, given that the highest concentration of $\mathrm{E} 12_{\mathrm{bHLH}}$ used in the binding analysis was $\sim 2 \mu \mathrm{M}$ the effect of E12 $\mathrm{bHLH}$ homodimerization should be negligible. On the other hand TAL $1_{\text {bHLH }}$ homodimerization could have competed with heterodimer formation. To determine the extent of this, isotherms were simulated in Mathematica using the competitive binding between TAL1 $1_{\mathrm{bHLH}}$ homodimerization (with $K_{\mathrm{TT}}=5.3 \times 10^{6} \mathrm{M}^{-1}$ ) and $\mathrm{TAL}_{\mathrm{bHLH}^{-}} \mathrm{E} 12_{\mathrm{bHLH}}$ heterodimerization, where $K_{\mathrm{TE}}$ was set to values ranging from $2 \times 10^{6}$ to $2 \times 10^{8} M^{-1}$. The simulated data best mimicked the experimental data when $K_{\mathrm{TE}}$ was set to values between $3 \times 10^{7}$ and $5 \times 10^{7} M^{-1}$ [Fig. 5(c)]; this compares well with that for $K_{\mathrm{TE}}$ obtained using the standard non-competitive model $\left(3.5 \times 10^{7} M^{-1}\right)$ so it was used as a close approximation to $K_{\mathrm{TE}}$. It is almost an order of magnitude larger than the homodimerization constant for TAL1 $1_{\mathrm{bHLH}}$ indicating a clear preference of these proteins to form heterodimers rather than homodimers.

\section{The formation of multiprotein DNA-containing complexes}

It was previously shown that full length LMO2, Ldb1, TAL1, and E2A proteins can form multiprotein complexes in cell lines, 16,17 and that LMO2 and TAL1 can directly interact in mammalian two-hybrid systems. ${ }^{42}$ To determine if $\mathrm{LMO} 2-\mathrm{Ldb} 1_{\mathrm{LID}}, \mathrm{TAL}_{\mathrm{bHLH}}$, and $\mathrm{E} 12_{\mathrm{bHLH}}$ can form multiprotein complexes on DNA, electrophoretic mobility shift assays (EMSAs) were carried out using a radiolabeled EboxGG probe [Fig. 6(a)]. Here MBP-E12 ${ }_{\mathrm{bHLH}}(\sim 50 \mathrm{kDa})$ was used to maximise shifts and distinguish between different proteins. MBP-E12 $2_{\mathrm{bHLH}}$ appeared to specifically bind the probe (lane 3). However, TAL1 $1_{\text {bHLH }}$ appeared to form large non-specific TAL $1_{\text {bHLH }} /$ DNA aggregates that did not enter the gel (lane 2). This outcome was consistent with the previous report that isolated TAL1 does not exhibit any specific DNA-binding. ${ }^{43}$ We observed a similar phenomenon with a non-Ebox probe, and the addition of increasing amounts of poly-d $I \mathrm{~d} C$, heparin, or BSA reduced the amount of precipitated material, (data not shown).

The addition of both MBP-E12 $2_{\mathrm{bHLH}}$ and TAL $1_{\mathrm{bHLH}}$ to the DNA probe resulted in a band with a smaller shift than that of MBP-E12 ${ }_{\mathrm{bHLH}}$ alone (lane 6), suggesting binding of the smaller heterodimer.

LMO2-Ldb1 $1_{\text {LID }}$ induced an additional shift (lanes 7 and 8), implying that LMO2-Ldb $1_{\text {LID }}$ can bind to a $\mathrm{TAL}_{\mathrm{bHLH}} / \mathrm{MBP}-\mathrm{E} 12_{\mathrm{bHLH}}$ heterodimer on DNA. This was confirmed by the addition of either anti-HIS 6 (lane 9) or anti-MBP (lane 10) antibodies that are both able to produce an additional shift (supershift) of this complex. Control experiments showed that MBP-E12 bHLH was required for the complex to bind DNA (lane 12), and 
(a)

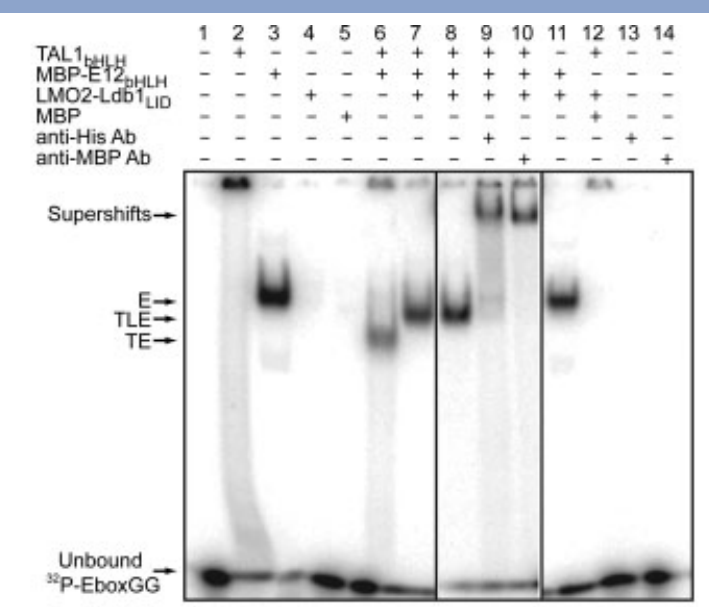

(b)
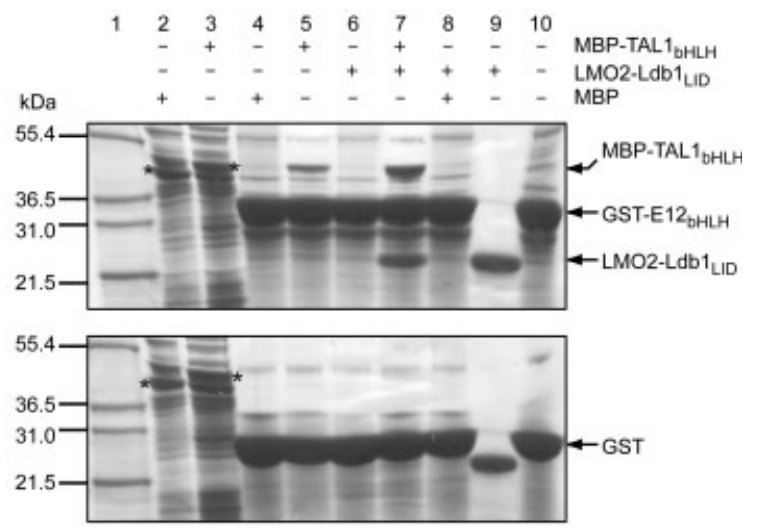

(c)

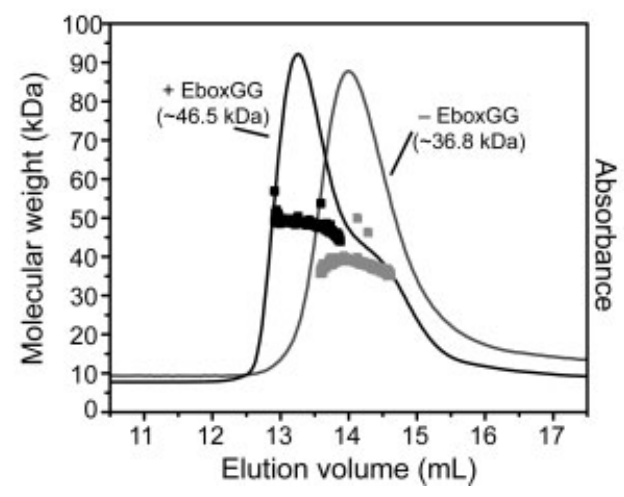

\section{Figure 6}

Analysis of the protein-protein and protein-DNA interaction network LMO2/ Ldb1/TAL1/E12/DNA complexes. + and - symbols indicate the inclusion or omission of the specific protein in the binding reaction. (a) EMSA analysis of EboxGG-binding by LMO2-Ldb1 $1_{L I D} / T A L 1_{b H L H} / E 12_{b H L H}$ complexes. MBP-

$E 12_{b H L H}, T A L_{b H L H}$, and MBP were all added to a final concentration of $\sim 2 \mu \mathrm{M}$ and LMO2-Ldb1 $1_{L I D}$ to a final concentration of $\sim 10 \mu \mathrm{M}$. Migration positions of $M B P-E 12_{b H L H} / D N A$ (E; lanes 3 and 11 ), TAL $1_{b H L H} / M B P-E 12_{b H L H} / D N A$ (TE; lane 6), LMO2/Ldb1 $1_{L I D} / T A L 1_{b H L H} / M B P-E 12_{b H L H} / D N A$ (TLE; lanes 7 and 8), antibody-supershifted complexes (lanes 9 and 10), and unbound ${ }^{32} P$-EboxGG are indicated. (b) GST-pulldown analysis of GST-E12 ${ }_{b H L H}, T A L 1_{b H L H}$, and LMO2-Ldb1 $1_{L I D}$ interactions. Asterisks in lanes 2 and 3 indicate the position of bands corresponding to $M B P$ and $M B P-T A L 1_{b H L H}$, respectively. Upper panel: pulldown experiments using GST-E12 $2_{b H L H}$ immobilised on GSH-resin. Lower panel: control pulldown experiments using GST immobilised on GSH-resin. Lanes 2, 3, and 9 represent 5\% input of the respective protein samples. (c) SEC/ MALLS analysis of a LMO2-Ldb1 $1_{L I D} / T A L 1_{b H L H} / E 12_{b H L H}$ complex in the presence (black) or absence (light grey) of EboxGG DNA. Solid lines represent absorbance and squares represent MALLS-calculated Mr. that $\mathrm{TAL} 1_{\mathrm{bHLH}}$ was required for $\mathrm{LMO} 2-\mathrm{Ldb} 1_{\mathrm{LID}}$ to take part in the complex (lane 11). This pattern of proteinprotein interactions was also observed in GST-pulldown experiments carried out in the absence of DNA [Fig. 6(b)]. GST-E12 ${ }_{\text {bHLH }}$ could retain MBP-TAL1 $1_{\text {bHLH }}$ (lane 5 upper panel) but not LMO2-Ldb1 LID (lane 6 upper panel). However, LMO2-Ldb1 $1_{\text {LID }}$ was retained by GSTE12 ${ }_{\mathrm{bHLH}}$ in the presence of MBP-TAL1 $1_{\mathrm{bHLH}}$ (lane 7 upper panel). Control experiments using only GST-bound resin [Fig. 6(b) lower panel] and/or MBP (lanes 4 and 8) showed that the observed interactions were not due to the presence of the fusion-protein tags.

Samples of heterodimeric TAL1 $1_{\mathrm{bHLH}}-\mathrm{E} 12_{\mathrm{bHLH}}$ that had been isolated by SEC were mixed with an approximately equimolar amount of LMO2-Ldb1 $1_{\text {LID }}$ in the presence and absence of DNA and subjected to size exclusion chromatography monitored by multiangle laser light scattering analysis. This was done to determine the stoichiometries of the LMO2-Ldb1 $1_{\mathrm{LID}} / \mathrm{TAL} 1_{\mathrm{bHLH}} / \mathrm{E} 12_{\mathrm{bHLH}}$ complexes. The resulting species had a $\mathrm{Mr}$ of $36.8 \pm 2.2 \mathrm{kDa}$ [Fig. $6(\mathrm{c})]$, which correlates well with the theoretical value $(36.6 \mathrm{kDa})$ of a complex comprising a single molecule each of $\mathrm{TAL} 1_{\mathrm{bHLH}}, \mathrm{E} 12_{\mathrm{bHLH}}$, and LMO2-Ldb1 $1_{\mathrm{LID}}$. Addition of EboxGG resulted in an increase in the $\mathrm{Mr}$ (46.5 $\pm 1.5 \mathrm{kDa}$ ) [Fig. 6(c)] that was consistent with the addition of one dsDNA molecule $(8.5 \mathrm{kDa})$ to the protein heterotrimer.

\section{Measurement of LMOE-Ldb 1 LID binding to TAL $1_{\text {bHLH }}$ [ $K_{\mathrm{LI} \rightarrow \text { T }}$, TALbHLH/E $12_{\mathrm{bH} L H}$ [ $K_{\mathrm{LI} \rightarrow \text { TE }}$ ), and a TAL [KLI $\rightarrow$ TEGG}

A series of ITC experiments was carried out to characterize further the formation of this protein-DNA complex (see Fig. 7). LMO2-Ldb1 $1_{\mathrm{LID}}$ was titrated into TAL $1_{\text {bHLH }}$ to yield an association constant of $K_{\mathrm{Ll} \rightarrow \mathrm{T}}=$ $(6.3 \pm 1.4) \times 10^{5} M^{-1}$ [Fig. 7(a)]. As expected from our GST-pulldown data [Fig. 6(b)] and previous studies 42,44 no evidence of an interaction could be seen in a titration of LMO2-Ldb1 $1_{\text {LID }}$ into E12 ${ }_{\text {bHLH }}$ [Fig. 7(b)].

Strikingly, the titration of $\mathrm{LMO} 2-\mathrm{Ldb} 1_{\mathrm{LID}}$ into a preformed complex of $\mathrm{TAL}_{\mathrm{bHLH}} / \mathrm{E} 12_{\mathrm{bHLH}}$ yielded an association constant for this interaction of $K_{\mathrm{Ll} \rightarrow \mathrm{TE}}=(1.8 \pm$ $0.6) \times 10^{8} M^{-1}$ [Fig. 7(c)], nearly 300-fold stronger than $K_{\mathrm{Ll} \rightarrow \mathrm{T}}$. This preference for bHLH heterodimers was also evident in the GST-pulldown shown in Figure 6(b), as the presence of LMO2-Ldb1 $1_{\text {LID }}$ increased the amount of TAL $1_{\mathrm{bHLH}}$ retained by GST-E $12_{\mathrm{bHLH}}$.

A similar association constant was obtained when LMO2-Ldb $1_{\text {LID }}$ was titrated into a preformed complex comprising the bHLH heterodimer bound to DNA, $K_{\mathrm{Ll} \rightarrow \mathrm{TEGG}}=(1.7 \pm 0.9) \times 10^{8} \mathrm{M}^{-1}$. Thus, LMO2$\mathrm{Ldb}_{\mathrm{LID}}$ interacted with TAL1 $1_{\mathrm{bHLH}}$ with low affinity, but 
(a)

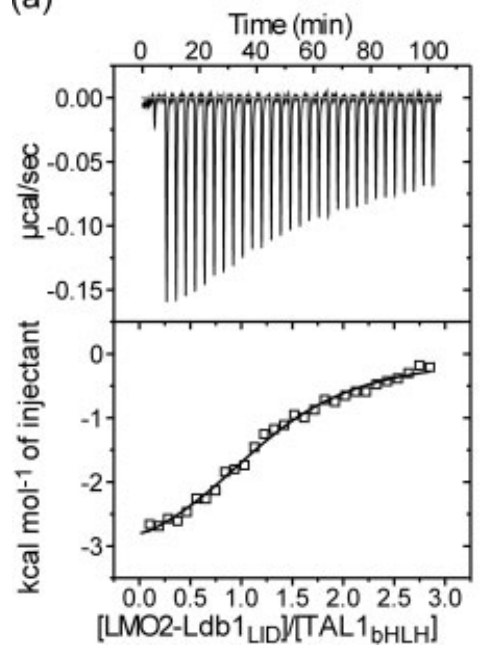

(b)

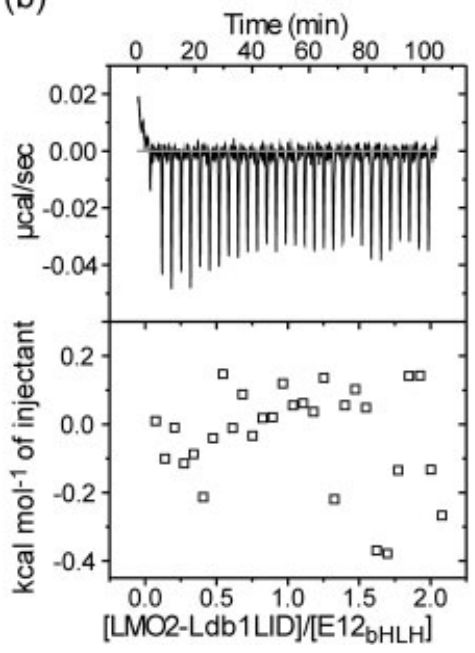

(c)

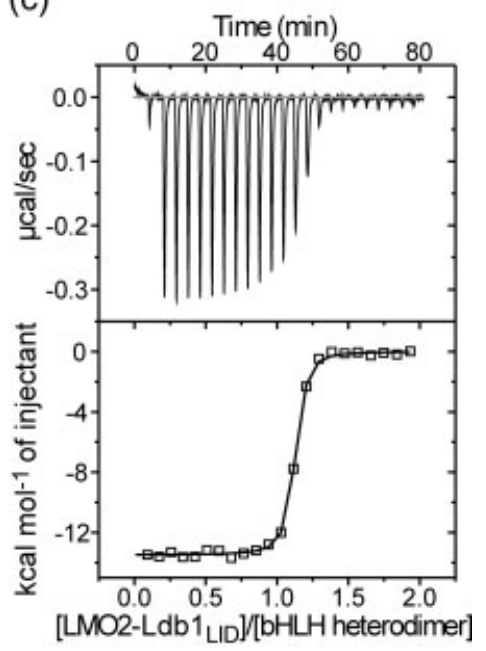

Figure 7

ITC data showing titrations of LMO2-Ldb1 $1_{L I D}$ into TAL1 $1_{b H L H}(\boldsymbol{a}), E 12_{b H L H}(\boldsymbol{b})$, and $T A L 1_{b H L H} / E 12_{b H L H}$ heterodimers (c) recorded at $25^{\circ} \mathrm{C}$.

preferentially bound the $\mathrm{TAL} 1_{\mathrm{bHLH}} / \mathrm{E} 12_{\mathrm{bHLH}}$ heterodimer, in the presence or absence of DNA.

\section{Measurement of EboxGG binding to E12 [KGG $K_{\text {E }}$ ], TALbHLH/E12 $2_{b H L H}$ [K $K_{G G \rightarrow T E}$ J, and a LMOE/Ldb 1 LID/TALbHLH/E12 complex [KK $K_{\mathrm{GG}-\mathrm{LITE}}$ ]}

When EboxGG DNA was added to the low concentration $(10 \mu M)$ E12 $2_{\mathrm{bHLH}}$ sample used for Figure $4(\mathrm{~d})$ there was a marked increase in helicity $81 \% \pm 5 \%$ estimated by far UV-CD, to levels similar to that when all the E12 ${ }_{\text {bHLH }}$ was present in an oligomeric form. This indicated that DNA-binding enhanced dimer formation of E12.

Using ITC, the titration of EboxGG into E12 $2_{\mathrm{bHL}}$ and $\mathrm{TAL}_{\mathrm{bHLH}} / \mathrm{E} 12_{\mathrm{bHLH}}$ indicated that $\mathrm{E} 12_{\mathrm{bHLH}}$ bound to that sequence more strongly than did the heterodimer; $K_{\mathrm{GG} \rightarrow \mathrm{E}}$ $=(4.3 \pm 0.2) \times 10^{7} M^{-1}$ versus $K_{\mathrm{GG} \rightarrow \mathrm{TE}}=(2.5 \pm 0.1)$ $\times 10^{6} M^{-1}$, respectively. When EboxGG was titrated into a preformed complex comprising LMO2-Ldb1 $1_{\text {LID }}$ and TAL $1_{\mathrm{bHLH}} / \mathrm{E} 12_{\mathrm{bHLH}}$ a slightly weaker binding constant was determined, $K_{\mathrm{GG} \rightarrow \mathrm{LITE}}=(1.7 \pm 0.1) \times 10^{6} \mathrm{M}^{-1}$. In this experiment there was evidence of a small initial binding event followed by a main transition. The data were fitted by a two-site binding model, where the $K_{\mathrm{A}}$ and $\Delta H$ of one site were constrained to the values determined for the titration of EboxGG into E12 Supplementary Data 3). Thus, the initial binding event was probably due to small amounts of free E12 $2_{\mathrm{bHLH}}$ in the ITC cell.

\section{Measurement of EboxGC binding to E12 [K $K_{\mathrm{GC} \rightarrow \mathrm{E}}$ ], TAL $L_{\mathrm{bHLH}} / \mathrm{E}_{1} 2_{\mathrm{bH} L \mathrm{H}}$ [K $K_{\mathrm{GC} \rightarrow \mathrm{TE}}$ ), and

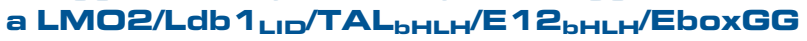 complex [K $K_{\text {SC-LTTE }}$ ]}

To investigate the sequence preferences of LMO2/ TAL1/E12 DNA-binding, a second Ebox motif was assayed for binding the various bHLH-containing complexes. This sequence (CTATCAGCTGATGA; EboxGC) was based on the promoter region of GPA, a target for regulation by LMO2/TAL1/E2A complexes. ${ }^{19}$ EboxGC bound E12 $2_{\mathrm{bLH}}$ with $\sim 30$-fold lower binding affinity than did EboxGG $\left[K_{\mathrm{GC} \rightarrow \mathrm{E}}=(1.6 \pm 0.1) \times 10^{6} \mathrm{M}^{-1}\right)$, and appeared to bind the bHLH heterodimer at approximately the same level $\left(K_{\mathrm{GC} \rightarrow \mathrm{TE}} \approx 1.5 \times 10^{6} \mathrm{M}^{-1}\right)$. However, this value was only an estimate as there was evidence of a second, unidentified binding event that could not be analyzed using simple binding models (see Supplementary Data 3).

Finally, EboxGC bound the LMO2/Ldb $1_{\mathrm{LID}} / \mathrm{TAL}_{\mathrm{bHLH}} /$ E12 ${ }_{\text {bHLH }}$ complex with $\sim 4$-fold lower affinity $\left(K_{\mathrm{GC} \rightarrow \text { LITE }}\right.$ $\left.=(4.0 \pm 0.8) \times 10^{5} \mathrm{M}^{-1}\right)$ than the E12 $\mathrm{bHLH}$ homodimer or the bHLH heterodimer.

\section{Simulations of complex formation}

Which of the complexes described earlier form in vivo depends on multiple competing equilibria (e.g., Fig. 1; Table I), and the concentrations (i.e., expression levels) of the different components. To gain insight into what might be taking place within a cellular context, we used the various association constants and equilibrium reaction schemes for the binding of these molecules (Table I) 
Table I

Summary of the Thermodynamic Parameters for the Protein-Protein and Protein-DNA Interactions Investigated in these Studies

\begin{tabular}{|c|c|c|c|c|c|}
\hline Equilibrium reaction & Symbol & $K_{\mathrm{A}}\left(\mathrm{M}^{-1}\right)$ & $\left.\Delta H(\mathrm{kcal} \mathrm{mol})^{-1}\right)$ & $-T \Delta S\left(\mathrm{kcal} \mathrm{mol}^{-1}\right)$ & $\Delta G_{298 \mathrm{~K}}\left(\mathrm{kcal} \mathrm{mol}^{-1}\right)$ \\
\hline \multicolumn{6}{|l|}{ Protein only reactions } \\
\hline $2 \mathrm{E} \leftrightarrow \mathrm{E}_{2}^{\mathrm{a}}$ & $K_{\mathrm{EE}}$ & $(7.4 \pm 0.6) \times 10^{4 a}$ & - & - & $-6.6 \pm<0.1$ \\
\hline $2 \mathrm{~T} \leftrightarrow \mathrm{T}_{2}$ & $K_{\mathrm{TT}}$ & $(5.3 \pm 0.3) \times 10^{6}$ & - & - & $-9.2 \pm<0.1$ \\
\hline $\mathrm{T}+\mathrm{E} \leftrightarrow \mathrm{TE}$ & $K_{\mathrm{TE}}$ & $(3.5 \pm 0.6) \times 10^{7}$ & - & - & $-10.3 \pm 0.1$ \\
\hline $\mathrm{L}+\mathrm{I} \leftrightarrow \mathrm{LI}$ & $K_{\mathrm{LI}}$ & $5 \times 10^{7 b}$ & - & - & -10.5 \\
\hline $\mathrm{LI}+\mathrm{E} \leftrightarrow \mathrm{LIE}$ & $K_{\mathrm{LI} \rightarrow \mathrm{E}}$ & $<10^{3}$ & - & - & - \\
\hline $\mathrm{LI}+\mathrm{T}_{2} \leftrightarrow \mathrm{LIT}_{2}$ & $K_{\mathrm{LI} \rightarrow \mathrm{T}}$ & $(6.3 \pm 1.4) \times 10^{5}$ & $-5.3 \pm 1.7$ & $-2.7 \pm 1.6$ & $-7.9 \pm 0.1$ \\
\hline $\mathrm{LI}+\mathrm{TE} \leftrightarrow \mathrm{LITE}$ & $K_{\mathrm{LI} \rightarrow \mathrm{TE}}$ & $(1.8 \pm 0.6) \times 10^{8}$ & $-11.9 \pm 2.2$ & $0.7 \pm 2.4$ & $-11.3 \pm 0.2$ \\
\hline \multicolumn{6}{|l|}{ EboxGG reactions } \\
\hline LI + TEGG $\leftrightarrow$ LITEGG & $K_{\mathrm{LI} \rightarrow \mathrm{TEGG}}$ & $(1.7 \pm 0.9) \times 10^{8}$ & $-10.3 \pm 1.0$ & $-0.9 \pm 1.3$ & $-11.2 \pm 0.3$ \\
\hline $\mathrm{GG}+2 \mathrm{E} \leftrightarrow \mathrm{E}_{2} \mathrm{GG}$ & $K_{\mathrm{GG} \rightarrow \mathrm{E}}$ & $(4.3 \pm 0.2) \times 10^{7}$ & $-40.9 \pm 0.1$ & 28.9 & $-9.7 \pm 0.1$ \\
\hline $\mathrm{GG}+\mathrm{TE} \leftrightarrow \mathrm{TEGG}$ & $K_{\mathrm{GG} \rightarrow \mathrm{TE}}$ & $(2.5 \pm 0.1) \times 10^{6}$ & $-38.0 \pm 0.4$ & 18.3 & $-8.8 \pm 0.4$ \\
\hline GG + LITE $\leftrightarrow$ LITEGG & $K_{\mathrm{GG} \rightarrow \mathrm{LITE}}$ & $(1.7 \pm 0.1) \times 10^{6}$ & $-26.8 \pm 0.5$ & 29.3 & $-8.5 \pm 0.5$ \\
\hline \multicolumn{6}{|l|}{ EboxGG reactions } \\
\hline $\mathrm{GC}+2 \mathrm{E} \leftrightarrow \mathrm{E}_{2} \mathrm{GG}$ & $K_{\mathrm{GC} \rightarrow \mathrm{E}}$ & $(1.6 \pm 0.1) \times 10^{6}$ & $-37.4 \pm 0.3$ & 31.1 & $-8.5 \pm 0.3$ \\
\hline $\mathrm{GC}+\mathrm{TE} \leftrightarrow \mathrm{TEGC}$ & $K_{\mathrm{GC} \rightarrow \mathrm{TE}}$ & $(1.5 \pm 0.4) \times 10^{6 \mathrm{c}}$ & $-38.3 \pm 0.3$ & $29.9 \pm 0.4$ & $-8.4 \pm 0.2$ \\
\hline GC + LITE $\leftrightarrow$ LITEGC & $K_{\mathrm{GC} \rightarrow \mathrm{LITE}}$ & $(4.0 \pm 0.8) \times 10^{5}$ & $-40.1 \pm 1.3$ & $32.4 \pm 1.2$ & $-7.7 \pm 0.1$ \\
\hline
\end{tabular}

T, TAL1 $1_{\text {bhlh }}$; E, E12 $2_{\text {bнLн }}$; L, LMO2; I, Ldb1 $1_{\text {LID }}$; GG, EboxGG; GC, EboxGC.

a The reaction scheme shown only shows the formation of homodimers; however, smaller amounts of higher order oligomers are also formed. The reported $K_{\mathrm{A}}$ is an apparent value, determined by assuming dimerisation only, and is used to indicating a relatively weak interaction.

${ }^{\mathrm{b}}$ This value has been reported previously and is shown only for comparison. ${ }^{24}$

'This value is an approximation only, due to initial deviations in the data from a standard sigmoidal shape that could not be accounted for in the fitting process (see supplementary data, Fig. S1).

to generate a mathematical model, by which we could simulate the formation and dissociation of all possible complexes in the scheme over time. This model was implemented in a Mathematica package MetabolicControlAnalysis 33 that was originally developed to model 2,3-bisphosphoglycerate metabolism in the human erythrocyte. 32

There are no available measurements of protein concentrations for these proteins within the nucleus. It was thus necessary to estimate concentrations of the components. Estimates of 1000-100,000 molecules of each transcription factor per eukaryotic cell, 45 and a nuclear volume of $10-20 \mathrm{fL}(\sim 10 \%$ of an average cell volume) yielded protein concentrations of $10 \mu M-100 \mathrm{n} M$. On rates for each of the equilibria were also estimated; the off rates were then calculated from the association constant. Regardless of numerical values of the on rate estimates (e.g., all diffusion limited $\left(K_{\text {on }} \times 10^{8} M^{-1} \mathrm{~s}^{-1}\right)$, all several orders of magnitude less, or a mixture of on rates) the schemes were dominated by the higher association constant reactions, although the time taken for various complexes to form obviously varied. Note that in this modeling we used E12 homodimerization rather than more complex models of self-association, but this should have little effect on the overall outcome as little E12 oligomerization should be seen at the protein concentrations used. When TAL1 was introduced to a system that contained E12 and the EboxGG binding site, E12 was largely sequestered into E12-TAL1 heterodimers, either as a protein-only heterodimer, or as a DNA-bound heterodimer. When LMO2 and Ldb1 were introduced along with TAL1, the predominant species were the protein-only TAL1/E12/LMO2/Ldb1 complex and the DNA bound version of this complex. If both the DNA sites used in this study (EboxGG and EboxGC) were included in the simulation, a similar situation arose, but both versions of the DNA bound complexes were present.

\section{DISCUSSION}

\section{Modeling competing equilibria}

Many cellular processes are under the control of multiprotein complexes or networks of protein-protein and other interactions. The detailed characterization of the multiple competing equilibria described in this study culminated in the construction of a mathematic model that allowed the distribution of the different components in different complexes and subcomplexes to be predicted, given a set of starting conditions. Within the cell, with changing levels of protein concentrations due to expression and degradation, it is unlikely that networks of interactions ever reach true equilibrium; therefore, a kinetic-based system provided a view of the changing distributions on the approach to equilibrium, despite a requirement for the estimation of on-rates.

There are limitations involved in trying to understand multicomponent complex formation as described in this study. The use of protein domains rather than whole proteins was necessary for implementation of many of 
the techniques employed; for example, full-length proteins could not be reasonably produced in sufficient quantity for ITC. It is possible that other parts of the proteins may influence complex formation; nevertheless, the detail provided by this approach reveals some important insights into the molecular basis of the biological function of TAL1, LMO2 and E12.

\section{TAL1/LMOE inhibition of E2A function}

Although both $\mathrm{TAL}_{\mathrm{bHLH}}$ and $\mathrm{E} 12_{\mathrm{bHLH}}$ can exist as homo-oligomers with association constants of $\sim 5 \times 10^{6}$ and $\sim 7 \times 10^{4} M^{-1}$, the two proteins preferentially form heterodimers with a dimerization constant $K_{\mathrm{A}}$ of $\sim 4 \times$ $10^{7} M^{-1}$ and an altered affinity for specific Ebox sequences. Thus, in leukaemic cells where TAL1 is ectopically expressed it is likely that TAL1 sequesters endogenous E2A proteins [Fig. 8(a)].

The binding affinities of LMO2 for TAL1/E12-containing complexes were the highest measured for any interactions in this study (Table I), including LMO2/Ldb1 interactions. $^{24}$ The sequestration of E2A proteins will, therefore, be much more strongly favoured in cells that express both TAL1 and LMO2 [Fig. 8(b)]. Thus, it is likely that TAL1 has a negative effect on E2A-mediated gene expression and lymphocyte development by preventing E2A proteins from forming specific transcriptional regulatory complexes, and that this effect is exacerbated by LMO2. These binding data provide a mechanism for how TAL1 and LMO2 synergistically contribute to T-ALL 6 and downregulate E2A-mediated expression of genes, ${ }^{46}$ although there may be additional LMO2-only effects contributing to T-ALL progression.

This sequestration of E2A proteins by TAL1 and LMO2 may also act as a regulatory mechanism in other tissues. Particularly in multipotential precursor cells that may be primed with a range of opposing tissue/lineage specific factors, and the fate of the cell would be determined by factors that favour the activity of one group of these tissue specific factors. ${ }^{47,48}$ In this case, LMO2 would promote the formation of TAL1/E2A heterodimers and drive the development of haematopoietic cells. Indeed, evidence of such a mechanism does exist. TAL1, especially in the presence of LMO2, can hijack cells normally destined for muscle development and cause them to become haematopoietic progenitor cells. ${ }^{49,50}$ This potential switch-like role of LMO2 adds an extra layer of complexity to the functions of LIM-only proteins, which had been thought to act simply as scaffolds that bring together groups of proteins.

\section{DNA binding}

The functions of TAL1 in early haematopoietic development, 51 and in the TAL1-mediated induction of leukaemia in mice 22 appear to be independent of DNA-

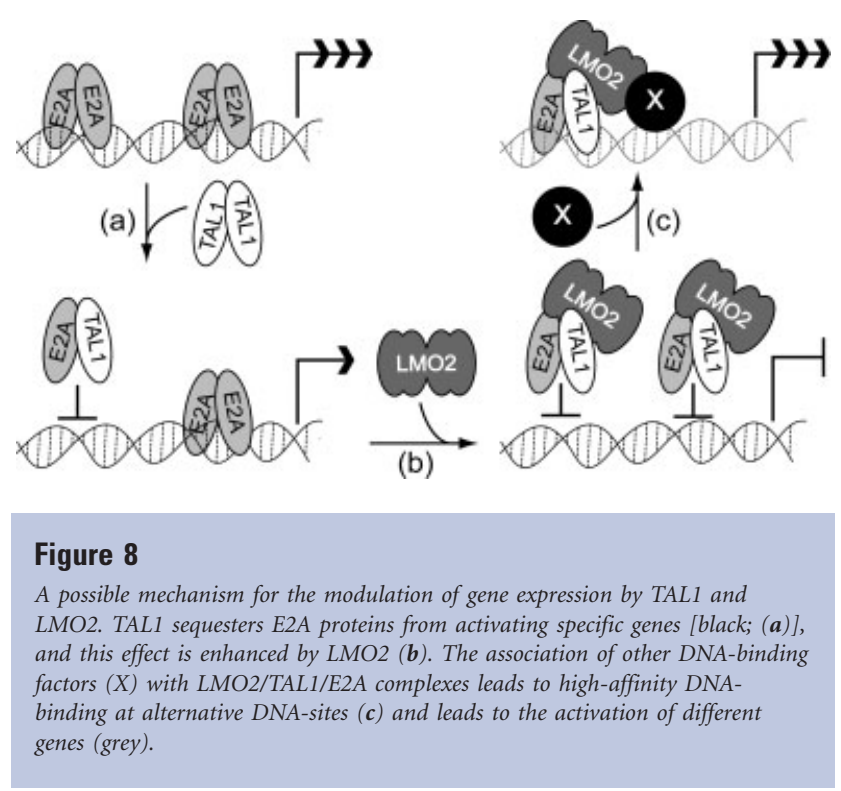

binding activity. However, the basic region of TAL1 is required for erythropoiesis and other later stages of blood cell development, 51,52 and is necessary for the control of at least two erythroid-specific genes, $P 4.2^{53}$ and GPA. ${ }^{19}$

The sequences of EboxGG and EboxGC come from the consensus sequence determined by site-selection experiments, ${ }^{16}$ and the promoter sequence of an actual target gene for TAL1/LMO2 complexes $\left(G P A ;{ }^{19}\right)$, respectively. It was therefore surprising to find that those sequences bound TAL1/E12 heterodimers with only moderate affinity $\left(\sim 10^{6} \mathrm{M}^{-1}\right)$ in comparison to other estimates for DNA binding by TAL/E12 $\left(\sim 10^{9} M^{-1} ; 54,55\right)$. However, these previous studies show that DNA binding by TAL1/ E12 heterodimers is greatly affected by the sequence flanking the core Ebox motif-so much so that sequences that bind TAL1/E12 $2_{\mathrm{bHLH}}$ heterodimers with nanomolar affinity may not bind at a detectable level (by EMSA) when the bases flanking the Ebox are changed-and this is likely to account for the difference in binding affinities we report here. It has been noted that many putative TAL1/E12 target control sites do not contain favorable flanking sequences and that moderate to low DNA-binding affinities may in fact allow more flexibility in controlling the activity of TAL1/E2A complexes in vivo, ${ }^{54}$ which is consistent with our findings.

DNA-binding sites for LMO2/TAL1/E2A complexes are often bipartite in nature, comprising 1 or 2 Ebox motifs and/or a recognition sequence for another transcription factor. Thus far, GATA sites have been the most commonly identified non-Ebox motif in the bipartite sequences. ${ }^{16,19,53}$ The association of LMO2/TAL1/E2A complexes with GATA proteins would allow coupling of the 
DNA-binding affinities of TAL1/E2A heterodimers with those of GATA-1 $\left(10^{9} M^{-156}\right)$, to result in high-affinity DNA-binding [Fig. 8(c)]. The DNA-binding properties of TAL1/E2A heterodimers are also subject to post-translational modification. 57 These factors could all combine to allow enormous flexibility in the control that can be imparted by LMO2/TAL1/E2A complexes.

\section{Inhibitors of TAL1 and LMOE activity}

This detailed characterization of TAL1/E12/LMO2 binding pathways and complex formation enables us to also predict the best strategies for inhibiting aberrant TAL1 and LMO2 activity in T-ALL. By modifying our Mathematica binding model(s) to include inhibitors of different interactions with varying $K_{i}$ (binding affinity) values, it appears that selectively inhibiting a single interaction (say between LMO2 and TAL1) will only have a limited affect on restoring the formation of E12 homodimer-DNA complexes, even if single inhibitors with very high $K_{i}$ values $\left(10^{-15} M\right)$ are used. Rather, when two inhibitors were included (targeting the LMO2/TAL1 and TAL1/E12 interactions) that have much lower $K_{i}$ values $\left(10^{-9} M\right)$ significantly higher levels of E12 homodimer-DNA complexes are restored. Thus, it will likely be more effective to target multiple, rather than individual interactions to effectively inhibit the aberrant activity of TAL1 and LMO2 in T-ALL. This is likely to be generally true for many other systems where multiple interacting factors are involved.

In conclusion, our biophysical data demonstrate that although E12 homodimers can bind specific DNA sites with reasonable affinities, in the presence of TAL1 E12 preferentially forms heterodimers. This effect is exacerbated by the presence of LMO2, which preferentially binds the TAL1-E12 heterodimer. This directly supports a synergistic role for TAL1 and LMO2 in both normal haematopoiesis and the onset of leukemia. Furthermore, the combination of our experimental data with mathematical modeling strategies has underlined the importance of considering multiple interactions when developing inhibitors of complex pathways.

\section{ACKNOWLEDGMENTS}

We thank Ann Kwan and Joel Mackay for help with curve fitting. DPR and CL were supported by a Australian APAs. JMM was supported by the Viertel Foundation.

\section{REFERENCES}

1. Ferrando AA, Neuberg DS, Staunton J, Loh ML, Huard C, Raimondi SC, Behm FG, Pui CH, Downing JR, Gilliland DG, Lander ES, Golub TR, Look AT. Gene expression signatures define novel oncogenic pathways in $\mathrm{T}$ cell acute lymphoblastic leukemia. Cancer Cell 2002;1:75-87.

2. Begley CG, Green AR. The SCL gene: from case report to critical hematopoietic regulator. Blood 1999;93:2760-2770.
3. Boehm T, Foroni L, Kaneko Y, Perutz MF, Rabbitts TH. The rhombotin family of cysteine-rich LIM-domain oncogenes: distinct members are involved in T-cell translocations to human chromosomes 11 p15 and 11p13. Proc Natl Acad Sci USA 1991;88:4367-4371.

4. Larson RC, Fisch P, Larson TA, Lavenir I, Langford T, King G, Rabbitts TH. T cell tumours of disparate phenotype in mice transgenic for Rbtn-2. Oncogene 1994;9:3675-3681.

5. Kelliher MA, Seldin DC, Leder P. Tal-1 induces T cell acute lymphoblastic leukemia accelerated by casein kinase II $\alpha$. EMBO J 1996;15:5160-5166.

6. Larson RC, Lavenir I, Larson TA, Baer R, Warren AJ, Wadman I, Nottage K, Rabbitts TH. Protein dimerization between Lmo2 (Rbtn2) and Tal1 alters thymocyte development and potentiates $\mathrm{T}$ cell tumorigenesis in transgenic mice. EMBO J 1996;15:10211027.

7. Massari ME, Murre C. Helix-loop-helix proteins: regulators of transcription in eucaryotic organisms. Mol Cell Biol 2000;20:429-440.

8. Bach I. The LIM domain: regulation by association. Mech Dev 2000;91:5-17.

9. Aoyama M, Ozaki T, Inuzuka H, Tomotsune D, Hirato J, Okamoto Y, Tokita H, Ohira M, Nakagawara A. LMO3 interacts with neuronal transcription factor, HEN2, and acts as an oncogene in neuroblastoma. Cancer Res 2005;65:4587-4597.

10. Rabbitts TH. LMO T-cell translocation oncogenes typify genes activated by chromosomal translocations that alter transcription and developmental processes. Genes Dev 1998;12:2651-2657.

11. Visvader JE, Venter D, Hahm K, Santamaria M, Sum EYM, O’Reilly L, White D, Williams R, Armes J, Lindeman GJ. The LIM domain gene LMO4 inhibits differentiation of mammary epithelial cells in vitro and is overexpressed in breast cancer. Proc Natl Acad Sci USA 2001;98:14452-14457.

12. Porcher C, Swat W, Rockwell K, Fujiwara Y, Alt FW, Orkin SH. The $\mathrm{T}$ cell leukemia oncoprotein SCL/tal-1 is essential for development of all hematopoietic lineages. Cell 1996;86:47-57.

13. Yamada Y, Warren AJ, Dobson C, Forster A, Pannell R, Rabbitts TH. The T cell leukemia LIM protein Lmo2 is necessary for adult mouse hematopoiesis. Proc Natl Acad Sci USA 1998;95:3890-3895.

14. Robb L, Elwood NJ, Elefanty AG, Kontgen F, Li R, Barnett LD, Begley CG. The scl gene product is required for the generation of all hematopoietic lineages in the adult mouse. EMBO J 1996;15:41234129.

15. Warren AJ, Colledge WH, Carlton MB, Evans MJ, Smith AJ, Rabbitts TH. The oncogenic cysteine-rich LIM domain protein rbtn2 is essential for erythroid development. Cell 1994;78:45-57.

16. Wadman IA, Osada H, Grutz GG, Agulnick AD, Westphal H, Forster A, Rabbitts TH. The LIM-only protein Lmo2 is a bridging molecule assembling an erythroid, DNA-binding complex which includes the TAL1, E47, GATA-1 and Ldb1/NLI proteins. EMBO J 1997;16:3145-3157.

17. Valge-Archer VE, Osada H, Warren AJ, Forster A, Li J, Baer R, Rabbitts TH. The LIM protein RBTN2 and the basic helix-loop-helix protein TAL1 are present in a complex in erythroid cells. Proc Natl Acad Sci USA 1994;91:8617-8621.

18. Grutz GG, Bucher K, Lavenir I, Larson T, Larson R, Rabbitts TH. The oncogenic T cell LIM-protein Lmo2 forms part of a DNAbinding complex specifically in immature T cells. EMBO J 1998;17: 4594-4605.

19. Lahlil R, Lecuyer E, Herblot S, Hoang T. SCL assembles a multifactorial complex that determines glycophorin A expression. Mol Cell Biol 2004;24:1439-1452.

20. Bain G, Engel I, Robanus Maandag EC, te Riele HP, Voland JR, Sharp LL, Chun J, Huey B, Pinkel D, Murre C. E2A deficiency leads to abnormalities in $\alpha \beta$ T-cell development and to rapid development of T-cell lymphomas. Mol Cell Biol 1997;17:4782-4791.

21. O'Neil J, Shank J, Cusson N, Murre C, Kelliher M. TAL1/SCL induces leukemia by inhibiting the transcriptional activity of E47/HEB. Cancer Cell 2004;5:587-596. 
22. O’Neil J, Billa M, Oikemus S, Kelliher M. The DNA binding activity of TAL-1 is not required to induce leukemia/lymphoma in mice. Oncogene 2001;20:3897-3905.

23. Goldfarb AN, Lewandowska K. Inhibition of cellular differentiation by the SCL/tal oncoprotein: transcriptional repression by an Id-like mechanism. Blood 1995;85:465-471.

24. Ryan DP, Sunde M, Kwan AH, Marianayagam NJ, Nancarrow AL, vanden Hoven RN, Thompson LS, Baca M, Mackay JP, Visvader JE, Matthews JM. Identification of the key LMO2-binding determinants on Ldb1. J Mol Biol 2006;359:66-75.

25. Murphy JB, Kies MW. Note on spectrophotometric determination of proteins in dilute solutions. Biochim Biophys Acta 1960;45:382384 .

26. Sreerama N, Woody RW. Estimation of protein secondary structure from circular dichroism spectra: comparison of CONTIN, SELCON, and CDSSTR methods with an expanded reference set. Anal Biochem 2000;287:252-260.

27. Folta-Stogniew E, Williams K. Determination of molecular masses of proteins in solution: implementation of an HPLC size exclusion chromatography and laser light scattering service in a core laboratory. J Biomol Tech 1999;10:51-63.

28. Manickam DS, Bisht HS, Wan L, Mao G, Oupicky D. Influence of TAT-peptide polymerization on properties and transfection activity of TAT/DNA polyplexes. J Control Release 2005;102:293-306.

29. Johnson ML, Correia JJ, Yphantis DA, Halvorson HR. Analysis of data from the analytical ultracentrifuge by nonlinear least-squares techniques. Biophys J 1981;36:575-588.

30. Brown PH, Schuck P. Macromolecular size-and-shape distributions by sedimentation velocity analytical ultracentrifugation. Biophys J 2006;90:4651-4661.

31. Hayes DB, Laue T, Philo J. SEDNTERP. USA: University of New Hampshire; 1995.

32. Mulquiney PJ, Kuchel PW. Model of 2,3-bisphosphoglycerate metabolism in the human erythrocyte based on detailed enzyme kinetic equations: computer simulation and metabolic control analysis. Biochem J 1999;342 (Part 3):597-604.

33. Mulquiney PJ, Kuchel PW. Modelling metabolism with mathematica. Boca Raton, FL: CRC Press; 2003. 309 p.

34. Deane JE, Sum E, Mackay JP, Lindeman GJ, Visvader JE, Matthews JM. Design, production and characterization of FLIN2 and FLIN4: the engineering of intramolecular ldbl: LMO complexes. Protein Eng 2001;14:493-499.

35. Deane JE, Ryan DP, Sunde M, Maher MJ, Guss JM, Visvader JE, Matthews JM. Tandem LIM domains provide synergistic binding in the LMO4: Ldb1 complex. EMBO J 2004;23:3589-3598.

36. Erijman L, Lorimer GH, Weber G. Reversible dissociation and conformational stability of dimeric ribulose bisphosphate carboxylase. Biochemistry 1993;32:5187-5195.

37. Silva JL, Silveira CF, Junior AC, Pontes L. Dissociation of a native dimer to a molten globule monomer. Effects of pressure and dilution on the association equilibrium of arc repressor. J Mol Biol 1992;223:545-555.

38. Xu G, Weber G. Dynamics and time-averaged chemical potential of proteins: importance in oligomer association. Proc Natl Acad Sci USA 1982;79:5268-5271.

39. Kunne AG, Allemann RK. Covalently linking BHLH subunits of MASH-1 increases specificity of DNA binding. Biochemistry 1997; 36:1085-1091.
40. Wendt H, Thomas RM, Ellenberger T. DNA-mediated folding and assembly of MyoD-E47 heterodimers. J Biol Chem 1998;273:57355743.

41. Maleki SJ, Royer CA, Hurlburt BK. MyoD-E12 heterodimers and MyoD-MyoD homodimers are equally stable. Biochemistry 1997;36: 6762-6767.

42. Osada H, Grutz G, Axelson H, Forster A, Rabbitts TH. Association of erythroid transcription factors: complexes involving the LIM protein RBTN2 and the zinc-finger protein GATA1. Proc Natl Acad Sci USA 1995;92:9585-9589.

43. Hsu HL, Huang L, Tsan JT, Funk W, Wright WE, Hu JS, Kingston RE, Baer R. Preferred sequences for DNA recognition by the TAL1 helix-loop-helix proteins. Mol Cell Biol 1994;14:1256-1265.

44. Wadman I, Li J, Bash RO, Forster A, Osada H, Rabbitts TH, Baer R. Specific in vivo association between the bHLH and LIM proteins implicated in human T cell leukemia. EMBO J 1994;13:4831-4839.

45. Yang VW. Eukaryotic transcription factors: identification, characterization and functions. J Nutr 1998;128:2045-2051.

46. Herblot S, Steff AM, Hugo P, Aplan PD, Hoang T. SCL and LMO1 alter thymocyte differentiation: inhibition of E2A-HEB function and pre-T $\alpha$ chain expression. Nat Immunol 2000;1:138-144.

47. Orkin SH. Priming the hematopoietic pump. Immunity 2003;19: 633-634.

48. Enver T, Greaves M. Loops, lineage, and leukemia. Cell 1998;94:912.

49. Gering M, Rodaway AR, Gottgens B, Patient RK, Green AR. The SCL gene specifies haemangioblast development from early mesoderm. EMBO J 1998;17:4029-4045.

50. Gering M, Yamada Y, Rabbitts TH, Patient RK. Lmo2 and Scl/Tal1 convert non-axial mesoderm into haemangioblasts which differentiate into endothelial cells in the absence of Gata1. Development 2003;130:6187-6199.

51. Porcher C, Liao EC, Fujiwara Y, Zon LI, Orkin SH. Specification of hematopoietic and vascular development by the bHLH transcription factor SCL without direct DNA binding. Development 1999; 126:4603-4615.

52. Ravet E, Reynaud D, Titeux M, Izac B, Fichelson S, Romeo PH, Dubart-Kupperschmitt A, Pflumio F. Characterization of DNAbinding-dependent and -independent functions of SCL/TAL1 during human erythropoiesis. Blood 2004;103:3326-3335.

53. Xu Z, Huang S, Chang LS, Agulnick AD, Brandt SJ. Identification of a TAL1 target gene reveals a positive role for the LIM domainbinding protein Ldb1 in erythroid gene expression and differentiation. Mol Cell Biol 2003;23:7585-7599.

54. Gould KA, Bresnick EH. Sequence determinants of DNA binding by the hematopoietic helix-loop-helix transcription factor TAL1: importance of sequences flanking the E-box core. Gene Expr 1998;7:87-101.

55. Beltran AC, Dawson PE, Gottesfeld JM. Role of DNA sequence in the binding specificity of synthetic basic-helix-loop-helix domains. Chembiochem 2005;6:104-113.

56. Omichinski JG, Trainor C, Evans T, Gronenborn AM, Clore GM, Felsenfeld G. A small single-"finger" peptide from the erythroid transcription factor GATA-1 binds specifically to DNA as a zinc or iron complex. Proc Natl Acad Sci USA 1993;90:1676-1680.

57. Prasad KS, Brandt SJ. Target-dependent effect of phosphorylation on the DNA binding activity of the TAL1/SCL oncoprotein. J Biol Chem 1997;272:11457-11462. 